\title{
2011 Annual Industrial Wastewater Reuse Report for the Idaho National Laboratory Site's Advanced Test Reactor Complex Cold Waste Pond
}

February 2012

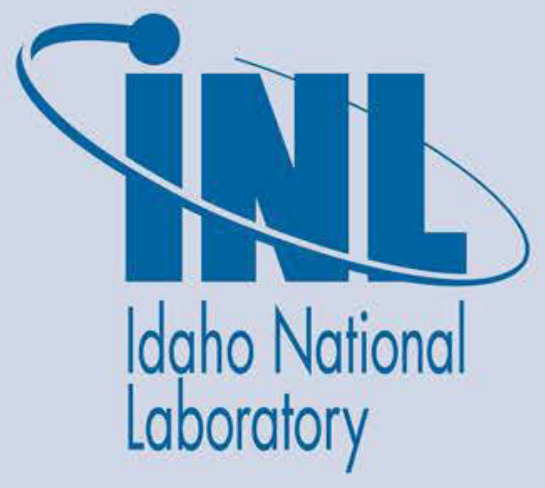

The INL is a U.S. Department of Energy National Laboratory operated by Battelle Energy Alliance 


\section{DISCLAIMER}

This information was prepared as an account of work sponsored by an agency of the U.S. Government. Neither the U.S. Government nor any agency thereof, nor any of their employees, makes any warranty, expressed or implied, or assumes any legal liability or responsibility for the accuracy, completeness, or usefulness, of any information, apparatus, product, or process disclosed, or represents that its use would not infringe privately owned rights. References herein to any specific commercial product, process, or service by trade name, trade mark, manufacturer, or otherwise, does not necessarily constitute or imply its endorsement, recommendation, or favoring by the U.S. Government or any agency thereof. The views and opinions of authors expressed herein do not necessarily state or reflect those of the U.S. Government or any agency thereof. 


\section{Annual Industrial Wastewater Reuse Report for the Idaho National Laboratory Site's Advanced Test Reactor Complex Cold Waste Pond}

February 2012

Idaho National Laboratory Idaho Falls, Idaho 83415

http://www.inl.gov

Prepared for the

U.S. Department of Energy

Office of Nuclear Energy

Under DOE Idaho Operations Office

Contract DE-AC07-05ID14517 



\begin{abstract}
This report describes conditions, as required by the state of Idaho Industrial Wastewater Reuse Permit (\#LA-000161-01, Modification B), for the wastewater land application site at the Idaho National Laboratory Site's Advanced Test Reactor Complex Cold Waste Pond from November 1, 2010 through October 31,2011 . The report contains the following information:

Facility and system description

Permit required effluent monitoring data and loading rates

Groundwater monitoring data

Status of compliance activities

Noncompliance and other issues

Discussion of the facility's environmental impacts

During the 2011 permit year, approximately 166 million gallons of wastewater were discharged to the Cold Waste Pond. This is well below the maximum annual permit limit of 375 million gallons. As shown by the groundwater sampling data, sulfate and total dissolved solids concentrations are highest near the Cold Waste Pond and decrease rapidly as the distance from the Cold Waste Pond increases. Although concentrations of sulfate and total dissolved solids are elevated near the Cold Waste Pond, both parameters were below the Ground Water Quality Rule Secondary Constituent Standards in the down gradient monitoring wells.
\end{abstract}




\section{CONTENTS}

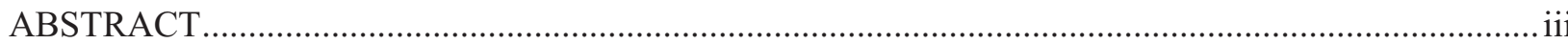

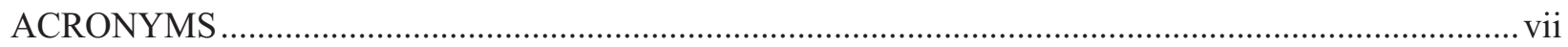

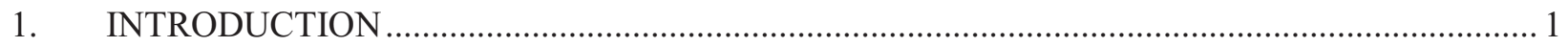

2. FACILITY, SYSTEM DESCRIPTION, AND OPERATION …................................................... 1

3. COLD WASTE POND EFFLUENT MONITORING ............................................................ 3

3.1 Sampling Program and Analytical Methods .................................................................... 3

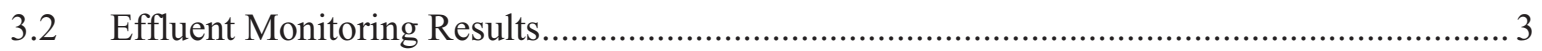

3.3 Flow Volumes and Hydraulic Loading Rates ............................................................... 7

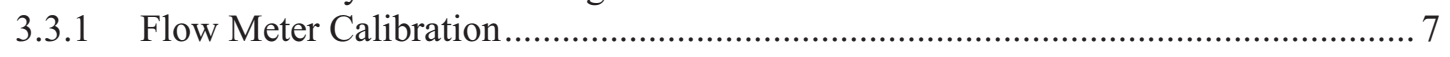

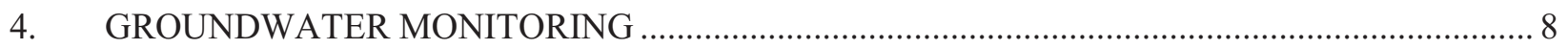

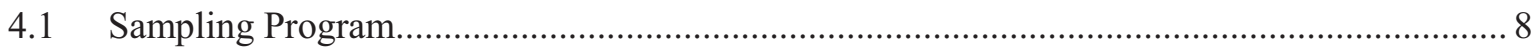

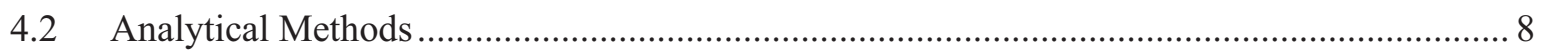

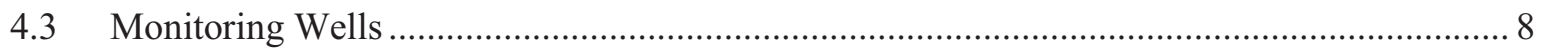

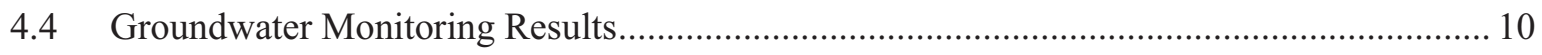

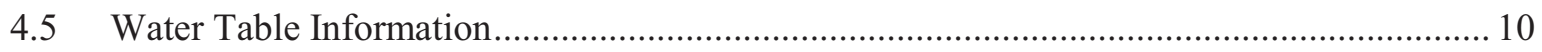

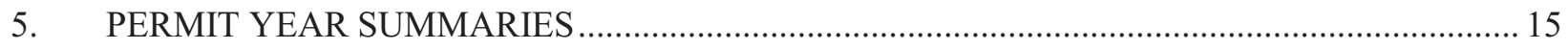

5.1 Status of Permit Required Compliance Activity ….......................................................... 15

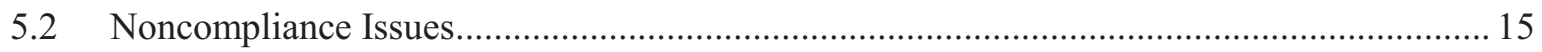

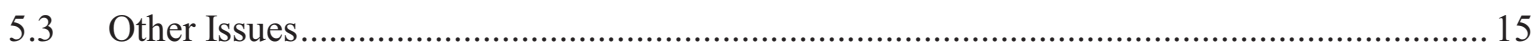

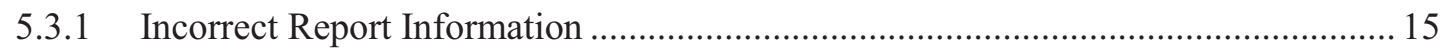

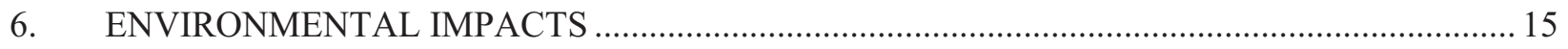

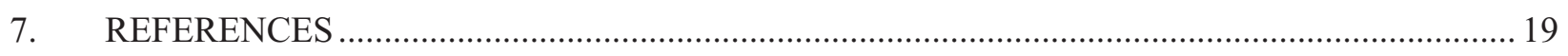

Appendix A Daily Discharge Volumes to the Advanced Test Reactor Complex Cold Waste Pond......... 21

\section{FIGURES}

Figure 1. Advanced Test Reactor Complex Cold Waste system flow schematic.

Figure 2. Locations of the Advanced Test Reactor Complex Cold Waste Pond Industrial

Wastewater Reuse Permit monitoring wells.

Figure 3. Groundwater contour map based on the April 2011 water level measurements........................ 13

Figure 4. Groundwater contour map based on the October 2011 water level measurements.................... 14 


\section{TABLES}

Table 1. Advanced Test Reactor Complex Cold Waste Pond effluent data (WW-016101).......................5

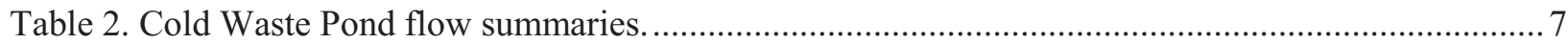

Table 3. Advanced Test Reactor Complex Cold Waste Pond aquifer monitoring well unfiltered and filtered (values are in parentheses) data for the 2011 reporting year................................. 11

Table 4. Comparison of 2011 results from unfiltered and filtered (values are in parentheses) samples collected from wells TRA-07 and TRA-08. .............................................................. 17

Table A-1. Daily discharge volumes to the ATR Complex CWP for the 2011 permit year..................... 23 


\section{ACRONYMS}

$\begin{array}{ll}\text { Al } & \text { Aluminum } \\ \text { ATR } & \text { Advanced Test Reactor } \\ \text { BEA } & \text { Battelle Energy Alliance, LLC } \\ \text { CFR } & \text { Code of Federal Regulations } \\ \text { CWP } & \text { Cold Waste Pond } \\ \text { DEQ } & \text { Idaho Department of Environmental Quality } \\ \text { Fe } & \text { Iron } \\ \text { gpd } & \text { gallons per day } \\ \text { IDAPA } & \text { Idaho Administrative Procedures Act } \\ \text { INL } & \text { Idaho National Laboratory } \\ \text { IWRP } & \text { Industrial Wastewater Reuse Permit } \\ \text { MG } & \text { Million gallons } \\ \text { Mn } & \text { Manganese } \\ \text { MS } & \text { Monitoring Services } \\ \text { NA } & \text { Not Applicable } \\ \text { PCS } & \text { Primary Constituent Standard } \\ \text { SCS } & \text { Secondary Constituent Standard } \\ \text { SwRI } & \text { Southwest Research Institute } \\ \text { TDS } & \text { total dissolved solids } \\ \text { TKN } & \text { total Kjeldahl nitrogen } \\ \text { TN } & \text { total nitrogen } \\ \text { TSS } & \text { total suspended solids } \\ \text { USGS } & \text { United States Geological Survey }\end{array}$




\section{Annual Industrial Wastewater Reuse Report for the Idaho National Laboratory Site's Advanced Test Reactor Complex Cold Waste Pond}

\section{INTRODUCTION}

The Advanced Test Reactor (ATR) Complex Cold Waste Pond (CWP) is an industrial wastewater reuse treatment facility operated by Battelle Energy Alliance, LLC (BEA) at the Idaho National Laboratory (INL) under Industrial Wastewater Reuse Permit (IWRP) \#LA-000161-01 issued by the state of Idaho Department of Environmental Quality (DEQ) on February 26, 2008, and will expire on February 25, 2013 (Johnston 2008). The permit was modified (Modification B) on August 20, 2008 (Eager 2008).

Following the Section 2 CWP facility, system, and operation description, this report presents the status of effluent and groundwater monitoring data, compliance activities, noncompliances, and environmental impacts of the CWP operation during the 2011 permit year (beginning November 1, 2010 through October 31, 2011).

\section{FACILITY, SYSTEM DESCRIPTION, AND OPERATION}

The ATR Complex (see Figure 1) is located on approximately 100 acres in the southwestern portion of the INL, approximately $47 \mathrm{mi}$. west of Idaho Falls, Idaho, in Butte County. The ATR Complex consists of buildings and structures utilized to conduct research associated with developing, testing, and analyzing materials used in nuclear and reactor applications and both radiological and nonradiological laboratory analyses.

The CWP is located approximately $450 \mathrm{ft}$ from the southeast corner of the ATR Complex compound (see Figure 1) and approximately $3 / 4$ of a mile southwest of the Big Lost River channel (see Figure 2). The existing CWP was excavated in 1982. It consists of two cells, each with dimensions of $180 \times 430 \mathrm{ft}$ across the top of the berms, and a depth of $10 \mathrm{ft}$. Total surface area for the two cells at the top of the berms is approximately 3.55 acres. Maximum capacity is approximately 10,220,000 gal (31.3 acre ft).

Wastewater discharged to the CWP consists primarily of noncontact cooling tower blowdown, once-through cooling water for air conditioning units, coolant water from air compressors, secondary system drains, and other nonradioactive drains throughout the ATR Complex. The wastewater flows through collection piping to the TRA-764 Cold Waste Sample Pit (see Figure 1) where the flow rate is recorded and compliance monitoring samples are collected. The wastewater then flows to the Cold Waste Sump Pit (TRA-703). The sump pit contains submersible pumps that route the water to the appropriate CWP cell through 8 in. valves.

Wastewater enters the pond through concrete inlet basins located near the west end of each cell. Most of the water percolates into the porous ground within a short distance from the inlet basins. The entire floor of a cell is rarely submerged. If the water level rises significantly in a cell (e.g., $5 \mathrm{ft}$ ) the flow would be diverted to the adjacent cell, allowing the first cell to dry out. An overflow pipe connects the two cells at the 9 -ft level.

Normal operation is to route the wastewater to one cell at a time. On July 20, 2011, the flow was switched from the south cell to the north cell. 


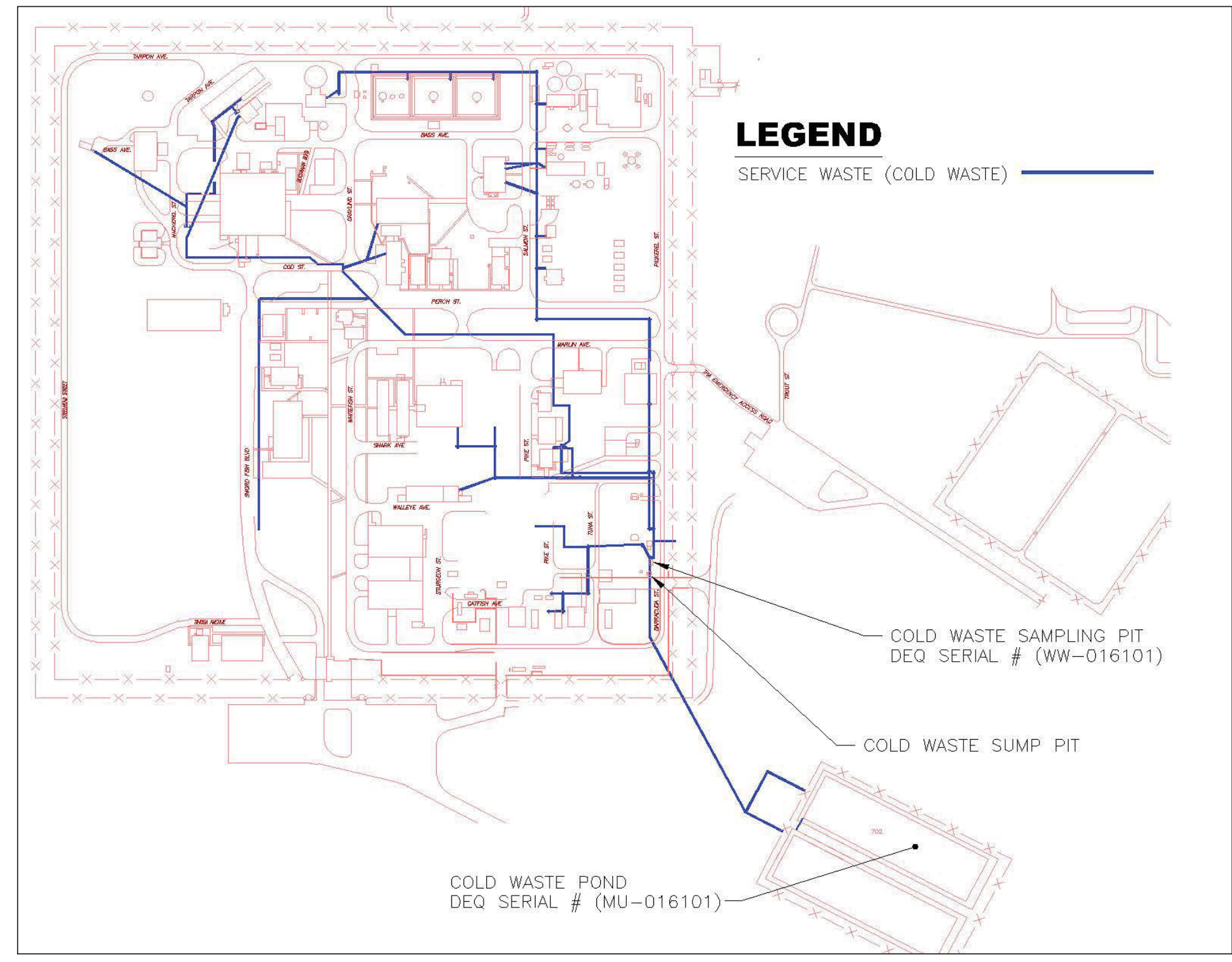

Figure 1. Advanced Test Reactor Complex Cold Waste system flow schematic. 


\section{COLD WASTE POND EFFLUENT MONITORING}

This section describes the sampling and analytical methods used in the ATR Complex CWP effluent monitoring program. Effluent monitoring and flow data of wastewater discharged to the ATR Complex CWP is provided.

\subsection{Sampling Program and Analytical Methods}

Monitoring Services (MS) at the INL monitors effluent discharges at the ATR Complex CWP. The MS program involves sampling, analysis, and data interpretation carried out under a quality assurance program.

MS conducts monthly effluent monitoring as required in Section $\mathrm{G}$ of the permit. Effluent samples were collected from the TRA-764 Cold Waste Sample Pit (sampling location WW-016101) prior to discharge to the CWP. All samples were collected according to established programmatic sampling procedures.

Effluent samples were taken during a preselected week each month following a randomly generated sampling schedule to represent normal operating conditions. Analytical methods specified in 40 Code of Federal Regulations (CFR) 141, "National Primary Drinking Water Regulations;" 40 CFR 143, "National Secondary Drinking Water Regulations;" 40 CFR 136, "Guidelines Establishing Test Procedures for the Analysis of Pollutants;" or those approved by DEQ were used for analysis of all permit-required parameters.

Permit required effluent conductivity analyses are performed at the time of sample collection by MS personnel using a calibrated meter. All other permit required samples are submitted under full chain of custody to Southwest Research Institute's (SwRI) Analytical and Environmental Chemistry Department located in San Antonio, Texas, for analyses.

\subsection{Effluent Monitoring Results}

The permit year covered in this report is from November 1, 2010, through October 31, 2011.

Effluent samples were collected monthly from the TRA-764 Cold Waste Sample Pit (prior to discharge to the CWP) during the permit year. Effluent samples were collected as 24-hour composite samples.

All samples were collected and analyzed as required by the permit. Table 1 summarizes the effluent sampling results.

Section F of the IWRP specifies effluent permit limits based on a 30-day average for total nitrogen (TN) and total suspended solids (TSS) of $20 \mathrm{mg} / \mathrm{L}$ and $100 \mathrm{mg} / \mathrm{L}$, respectively. Total nitrogen is calculated as the sum of total Kjeldahl nitrogen (TKN) and nitrate plus nitrite nitrogen. The high for TN occurred in December at $3.366 \mathrm{mg} / \mathrm{L}$ (see Table 1) with a low of $1.051 \mathrm{mg} / \mathrm{L}$ in February. All TSS results were below the laboratory instrument detection limit of $4 \mathrm{mg} / \mathrm{L}$.

There are no effluent permit limits for total dissolved solids (TDS) or sulfate. A summary comparison of these parameters with the Ground Water Quality Rule Secondary Constituent Standards (SCS) found in the Idaho Administrative Procedures Act (IDAPA) 58.01.11.200.01.b. follows.

The TDS SCS is $500 \mathrm{mg} / \mathrm{L}$. The concentration in the effluent to the CWP ranged from $241 \mathrm{mg} / \mathrm{L}$ in the February sample to $1,060 \mathrm{mg} / \mathrm{L}$ in the December sample (see Table 1). Concentrations of TDS in the effluent were above the SCS level in five out of the twelve months.

Similar to the TDS effluent levels, sulfate concentrations were above the SCS of $250 \mathrm{mg} / \mathrm{L}$ in four of the twelve monthly samples (see Table 1). Sulfate ranged from a minimum of $21.2 \mathrm{mg} / \mathrm{L}$ in the March sample to a maximum of $526 \mathrm{mg} / \mathrm{L}$ in the December sample. 
The ATR evaporative cooling process evaporates approximately one-half of the water volume and concentrates naturally occurring dissolved solids in the blowdown discharged to the CWP. Elevated sulfate levels are generated by reactions between sulfuric acid additives placed in the cooling water and calcium and magnesium carbonates in the water.

The metals concentrations in the CWP effluent remained at low levels (see Table 1). Concentrations of several metals in the effluent were consistently below the laboratory instrument detection levels. 
Table 1. Advanced Test Reactor Complex Cold Waste Pond effluent data (WW-016101).

\begin{tabular}{|c|c|c|c|c|c|c|c|c|c|c|c|c|}
\hline Sample Month & November & December & January & February & March & April & May & June & July $^{\mathrm{a}}$ & August & September & October \\
\hline Sample Date & $11 / 09 / 10$ & $12 / 07 / 10$ & $01 / 04 / 11$ & $02 / 08 / 11$ & $03 / 22 / 11$ & $04 / 19 / 11$ & $05 / 24 / 11$ & $06 / 09 / 11$ & $07 / 26 / 11$ & $08 / 17 / 11$ & 09/08/11 & $10 / 06 / 11$ \\
\hline $\begin{array}{l}\text { Nitrite + nitrate as nitrogen } \\
(\mathrm{mg} / \mathrm{L})\end{array}$ & 0.982 & 3.06 & 2.81 & 0.882 & 0.915 & 2.42 & 0.909 & 1.72 & $\begin{array}{c}2.82 \\
{[2.82]}\end{array}$ & 0.896 & 1.24 & 0.848 \\
\hline $\begin{array}{l}\text { Total Kjeldahl nitrogen } \\
(\mathrm{mg} / \mathrm{L})\end{array}$ & 0.416 & 0.306 & 0.467 & 0.169 & 0.239 & 0.451 & 0.156 & 0.315 & $\begin{array}{c}0.354 \\
{[0.228]}\end{array}$ & 0.187 & 0.25 & 0.227 \\
\hline Total nitrogen ${ }^{\mathrm{b}}(\mathrm{mg} / \mathrm{L})$ & 1.398 & 3.366 & 3.277 & 1.051 & 1.154 & 2.871 & 1.065 & 2.035 & $\begin{array}{c}3.174 \\
{[3.048]}\end{array}$ & 1.083 & 1.49 & 1.075 \\
\hline Total suspended solids $(\mathrm{mg} / \mathrm{L})$ & $4.0 \mathrm{U}^{\mathrm{c}}$ & $4.0 \mathrm{U}$ & $4.0 \mathrm{U}$ & $4.0 \mathrm{U}$ & $4.0 \mathrm{U}$ & $4.0 \mathrm{U}$ & $4.0 \mathrm{U}$ & $4.0 \mathrm{U}$ & $\begin{array}{c}4.0 \mathrm{U} \\
{[4.0 \mathrm{U}]}\end{array}$ & $4.0 \mathrm{U}$ & $4.0 \mathrm{U}$ & $4.0 \mathrm{U}$ \\
\hline Total dissolved solids (mg/L) & 330 & 1,060 & 968 & 241 & 243 & 847 & 272 & 642 & $\begin{array}{c}956 \\
{[970]}\end{array}$ & 282 & 411 & 296 \\
\hline Chloride $(\mathrm{mg} / \mathrm{L})$ & 34.1 & 33.9 & 31 & 10.2 & 10.4 & 34.4 & 10.6 & 31.8 & $\begin{array}{c}35.3 \\
{[35.5]}\end{array}$ & 12.3 & 19 & 16 \\
\hline $\begin{array}{l}\text { Electrical conductivity } \\
(\mu \mathrm{S} / \mathrm{cm})\end{array}$ & 538 & 1,313 & 1,341 & 460 & 437 & 1,114 & 443 & 881 & 1,262 & 495 & 663 & 491 \\
\hline Arsenic $(\mathrm{mg} / \mathrm{L})$ & $0.005 \mathrm{U}$ & 0.0057 & $0.005 \mathrm{U}$ & $0.005 \mathrm{U}$ & $0.005 \mathrm{U}$ & $0.005 \mathrm{U}$ & $0.005 \mathrm{U}$ & $0.005 \mathrm{U}$ & $\begin{array}{c}0.005 \mathrm{U} \\
{[0.005 \mathrm{U}]}\end{array}$ & $0.005 \mathrm{U}$ & $0.005 \mathrm{U}$ & $0.005 \mathrm{U}$ \\
\hline Barium $(\mathrm{mg} / \mathrm{L})$ & 0.0499 & 0.145 & 0.145 & 0.0489 & 0.0482 & 0.150 & 0.0466 & 0.0882 & $\begin{array}{c}0.132 \\
{[0.130]} \\
\end{array}$ & 0.0468 & 0.059 & 0.0467 \\
\hline Cadmium (mg/L) & $0.001 \mathrm{U}$ & $0.001 \mathrm{U}$ & $0.001 \mathrm{U}$ & $0.001 \mathrm{U}$ & $0.001 \mathrm{U}$ & $0.001 \mathrm{U}$ & $0.001 \mathrm{U}$ & $0.001 \mathrm{U}$ & $\begin{array}{c}0.001 \mathrm{U} \\
{[0.001 \mathrm{U}]}\end{array}$ & $0.001 \mathrm{U}$ & $0.001 \mathrm{U}$ & $0.001 \mathrm{U}$ \\
\hline Chromium (mg/L) & 0.0042 & 0.0111 & 0.0101 & 0.0037 & 0.004 & 0.0101 & 0.0029 & 0.0051 & $\begin{array}{c}0.0058 \\
{[0.0062]}\end{array}$ & 0.0028 & 0.0044 & 0.0042 \\
\hline Cobalt (mg/L) & $0.0025 \mathrm{U}$ & $0.0025 \mathrm{U}$ & $0.0025 \mathrm{U}$ & $0.0025 \mathrm{U}$ & $0.0025 \mathrm{U}$ & $0.0025 \mathrm{U}$ & $0.0025 \mathrm{U}$ & $0.0025 \mathrm{U}$ & $\begin{array}{c}0.0025 \mathrm{U} \\
{[0.0025 \mathrm{U}]}\end{array}$ & $0.0025 \mathrm{U}$ & $0.0025 \mathrm{U}$ & $0.0025 \mathrm{U}$ \\
\hline Copper (mg/L) & 0.0022 & 0.0043 & 0.0033 & $0.001 \mathrm{U}$ & 0.0015 & 0.0108 & 0.0018 & 0.0074 & $\begin{array}{c}0.0053 \\
{[0.0053]}\end{array}$ & 0.0013 & 0.0023 & 0.0032 \\
\hline Fluoride $(\mathrm{mg} / \mathrm{L})$ & 0.131 & 0.491 & 0.456 & 0.179 & 0.191 & 0.401 & 0.183 & 0.314 & $\begin{array}{c}0.421 \\
{[0.425]}\end{array}$ & 0.207 & 0.246 & 0.195 \\
\hline Iron $(\mathrm{mg} / \mathrm{L})$ & 0.109 & 0.169 & 0.165 & $0.025 \mathrm{U}$ & 0.0448 & 0.174 & $0.025 \mathrm{U}$ & 0.078 & $\begin{array}{c}0.101 \\
{[0.101]}\end{array}$ & 0.0555 & 0.0896 & 0.0943 \\
\hline Manganese $(\mathrm{mg} / \mathrm{L})$ & $0.0025 \mathrm{U}$ & $0.0025 \mathrm{U}$ & $0.0025 \mathrm{U}$ & $0.0025 \mathrm{U}$ & $0.0025 \mathrm{U}$ & 0.0134 & $0.0025 \mathrm{U}$ & 0.0036 & $\begin{array}{c}0.0028 \\
{[0.0027]}\end{array}$ & $0.0025 \mathrm{U}$ & $0.0025 \mathrm{U}$ & $0.0025 \mathrm{U}$ \\
\hline Mercury (mg/L) & $0.0002 \mathrm{U}$ & $0.0002 \mathrm{U}$ & $0.0002 \mathrm{U}$ & $0.0002 \mathrm{U}$ & $0.0002 \mathrm{U}$ & $0.0002 \mathrm{U}$ & $0.0002 \mathrm{U}$ & $0.0002 \mathrm{U}$ & $\begin{array}{c}0.0002 \mathrm{U} \\
{[0.0002 \mathrm{U}]}\end{array}$ & $0.0002 \mathrm{U}$ & $0.0002 \mathrm{U}$ & $0.0002 \mathrm{U}$ \\
\hline Selenium (mg/L) & 0.0014 & 0.0043 & 0.0036 & 0.001 & 0.001 & 0.0031 & 0.0011 & 0.0022 & $\begin{array}{c}0.0048 \\
{[0.0045]}\end{array}$ & 0.0015 & 0.0019 & 0.0012 \\
\hline
\end{tabular}




\begin{tabular}{|c|c|c|c|c|c|c|c|c|c|c|c|c|}
\hline Sample Month & November & December & January & February & March & April & May & June & $J_{u l y}{ }^{a}$ & August & September & October \\
\hline Sample Date & $11 / 09 / 10$ & $12 / 07 / 10$ & $01 / 04 / 11$ & $02 / 08 / 11$ & $03 / 22 / 11$ & 04/19/11 & $05 / 24 / 11$ & $06 / 09 / 11$ & $07 / 26 / 11$ & 08/17/11 & 09/08/11 & $10 / 06 / 11$ \\
\hline Silver $(\mathrm{mg} / \mathrm{L})$ & $0.005 \mathrm{U}$ & $0.005 \mathrm{U}$ & $0.005 \mathrm{U}$ & $0.005 \mathrm{U}$ & $0.005 \mathrm{U}$ & $0.005 \mathrm{U}$ & $0.005 \mathrm{U}$ & $0.005 \mathrm{U}$ & $\begin{array}{c}0.005 \mathrm{U} \\
\lceil 0.005 \mathrm{U}\rceil\end{array}$ & $0.005 \mathrm{U}$ & $0.005 \mathrm{U}$ & $0.005 \mathrm{U}$ \\
\hline Sulfate $(\mathrm{mg} / \mathrm{L})$ & 44.4 & 526 & 477 & 21.8 & 21.2 & 372 & 21.9 & 239 & $\begin{array}{c}474 \\
{[470]}\end{array}$ & 40.7 & 128 & 60.9 \\
\hline
\end{tabular}




\subsection{Flow Volumes and Hydraulic Loading Rates}

Daily flow readings were taken by ATR Complex CWP Operations during the 2011 permit year, as required by Section G of the permit, at the TRA-764 Cold Waste Sample Pit (WW-016101). All flow readings were recorded in gallons per day (gpd).

The July 20, 2011, flow volume of 141,580 gallons (see Appendix A) is a combination of recorded flow and estimated flow due to a power outage to the flow meter and totalizer that lasted approximately 6 hours and 20 minutes (see Section 5.2 for additional information).

Table 2 summarizes monthly and annual flow data. Daily effluent flow data is provided in Appendix A.

Table 2. Cold Waste Pond flow summaries.

\begin{tabular}{lcccr}
\hline & \multicolumn{3}{c}{ Effluent to Cold Waste Pond (WW-016101) } \\
\cline { 2 - 5 } \multicolumn{1}{c}{ Month } & $\begin{array}{c}\text { Average } \\
\left(\mathrm{gpd}^{\mathrm{a}}\right)\end{array}$ & $\begin{array}{c}\text { Minimum } \\
(\mathrm{gpd})\end{array}$ & $\begin{array}{c}\text { Maximum } \\
(\mathrm{gpd})\end{array}$ & $\begin{array}{r}\text { Total } \\
\left(\mathrm{MG}^{\mathrm{b}}\right)\end{array}$ \\
\hline November 2010 & 445,918 & 162,700 & 780,000 & 13.38 \\
December 2010 & 260,951 & 198,960 & 314,320 & 8.09 \\
January 2011 & 536,468 & 201,230 & 761,840 & 16.63 \\
February 2011 & 630,371 & 455,960 & 880,000 & 17.65 \\
March 2011 & 697,686 & 538,320 & 954,430 & 21.63 \\
April 2011 & 506,177 & 241,700 & $1,038,490$ & 15.19 \\
May 2011 & 482,937 & 240,410 & 872,010 & 14.97 \\
June 2011 & 320,721 & 129,910 & 840,000 & 9.62 \\
July 2011 & 270,799 & 132,500 & 840,000 & 8.39 \\
August 2011 & 422,785 & 195,400 & 638,840 & 13.11 \\
September 2011 & 630,259 & 359,510 & 846,670 & 18.91 \\
October 2011 & 258,327 & 90,520 & 461,850 & 8.01 \\
Yearly summary & 453,620 & 90,520 & $1,038,490$ & 165.57 \\
\hline a. gpd-gallons per day. & & & & \\
b. MG--million gallons. & & & & \\
\hline
\end{tabular}

The permit (Section F) specifies the following:

Application season is year round.

Maximum hydraulic loading rate is 300 million gallons (MG) as a 5-year annual average, not to exceed 375 MG annually.

Daily influent flow averaged 453,620 gpd. Daily flow ranged from a low of 90,520 gpd and a high of $1,038,490$ gpd for the permit year.

Total effluent flow volume was $165.57 \mathrm{MG}$ for the 2011 permit year and significantly less than the maximum permit limit of $375 \mathrm{MG}$ annually.

\subsubsection{Flow Meter Calibration}

Section G of the IWRP requires calibration of all flow meters and pumps used directly or indirectly to measure all wastewater applied to the CWP. The flow meter used to measure the flow volume to the CWP is located in the TRA-764 Cold Waste Sample Pit. The flow meter was calibrated on June 6, 2011, by the 
ATR Complex maintenance organization (work order \#157142). The calibration was performed to $+/-2 \%$ of full scale.

\section{GROUNDWATER MONITORING}

The groundwater monitoring sections provide information concerning the INL sampling program, analytical methods used, monitoring results, and water table information.

\subsection{Sampling Program}

The ATR Complex CWP IWRP identifies five INL compliance wells. The permit requires that groundwater samples be collected from these five compliance wells semiannually during April and October.

The MS personnel performed the April and October 2011 groundwater sampling. The MS personnel use project-specific sampling and analysis plans and procedures that govern sampling activities and quality control protocols. The permit identifies a specified list of parameters that are to be analyzed in the groundwater samples. Constituent concentrations in the compliance wells are limited by primary constituent standards (PCS) and SCS specified in IDAPA 58.01.11, "Ground Water Quality Rule."

Permit-required samples were collected as unfiltered samples. In addition, filtered samples for SCS metals analyses were also collected.

The Ground Water Quality Rule allows the use of dissolved (filtered) concentrations for SCS to be used for permit compliance provided the requestor demonstrates that doing so will not adversely affect human health and the environment or other situations authorized by the DEQ in writing. The INL submitted a request on October 8, 2009 (Stenzel 2009). The DEQ (Rackow 2010) responded with the following statement: "Filtered ground water samples may be collected for secondary constituents and the dissolved concentration results from those filtered samples will be used to determine compliance with the Ground Water Quality Rule numerical standards for those secondary constituents listed in Table III, IDAPA 58.01.11.200.01.b." Therefore, filtered SCS sample results will be used to demonstrate compliance with the IWRP.

Groundwater $\mathrm{pH}$ analyses are performed at the time of sample collection by MS personnel using a calibrated meter. All other permit required groundwater samples are submitted under full chain of custody to SwRI's Analytical and Environmental Chemistry Department located in San Antonio, Texas, for analyses.

\subsection{Analytical Methods}

Analytical methods specified in 40 CFR 141, "National Primary Drinking Water Regulations;" 40 CFR 143, "National Secondary Drinking Water Regulations;" 40 CFR 136, "Guidelines Establishing Test Procedures for the Analysis of Pollutants;" or those approved by DEQ were used for analysis of all permit-required parameters.

\subsection{Monitoring Wells}

To measure potential impacts to groundwater from the ATR Complex CWP, the permit requires that groundwater samples be collected from five monitoring wells located in the Snake River Plain Aquifer (see Figure 2):

- USGS-065 (GW-016102)

- TRA-07 (GW-016103)

- USGS-076 (GW-016104)

- TRA-08 (GW-016105)

- Middle-1823 (GW-016106). 


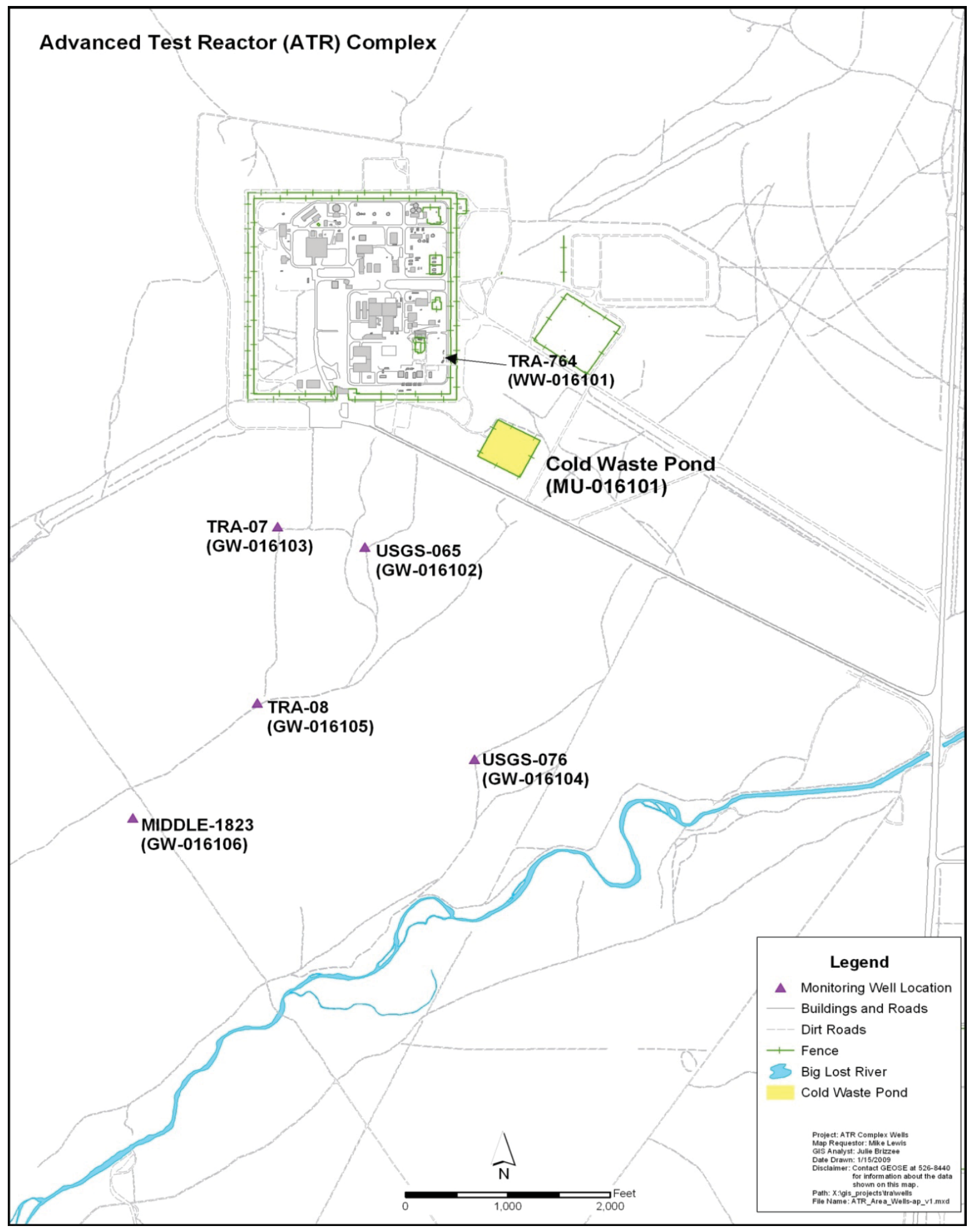

Figure 2. Locations of the Advanced Test Reactor Complex Cold Waste Pond Industrial Wastewater Reuse Permit monitoring wells. 
All five wells are IWRP compliance points. Wells with sufficient water volume are purged to a minimum of three casing volumes or one well volume, provided the field measurements meet the conditions specified in Section G.5 of the IWRP. For 2011, all five wells yielded enough water to allow samples to be collected in April and October.

\subsection{Groundwater Monitoring Results}

Table 3 shows the 2011 reporting year water table elevations and depth to water table, determined prior to purging and sampling, and the analytical results for all parameters specified by the permit for the five aquifer wells. Samples were collected from all five wells in both April and October.

As shown in Table 3, the permit-required parameters were below their respective Ground Water Quality Rule (IDAPA 58.01.11) PCSs or SCSs (permit compliance unfiltered and/or filtered concentrations) during the 2011 reporting year for all wells associated with the ATR Complex CWP.

However, both aluminum $(\mathrm{Al})$ and iron $(\mathrm{Fe})$ were above their respective SCSs in the unfiltered samples collected from wells TRA-07 and TRA-08 during the April and October sampling events. In comparison, the April- and October-filtered $\mathrm{Al}$ and Fe sample results, those used for determining permit compliance, were well below their SCSs in the two wells.

The SCS for manganese in well TRA-07 was exceeded in the unfiltered October sample, but not in the April sample. This was similar to the 2010 April and October sample results for well TRA-07, where the unfiltered October sample result was above the SCS but the April sample result was below. The 2011 April and October unfiltered manganese results in TRA- 08 were both below the SCS. The filtered sample results for manganese, used for determining permit compliance, in both wells were below the SCS.

Monitoring well USGS-065 and TRA-07 are located southwest of the CWP. Both wells show similar elevated levels of sulfate and TDS in the April and October 2011 samples (see Table 3). The SCS for sulfate and TDS are $250 \mathrm{mg} / \mathrm{L}$ and $500 \mathrm{mg} / \mathrm{L}$, respectively. Both the April and October 2011 sample results from these two wells were below the sulfate and TDS SCS limits. Sulfate and TDS concentrations in the two wells for April and October 2011 were similar to the April and October 2009 and 2010 sample results.

\subsection{Water Table Information}

Depth to water and water table elevations for the April and October sampling events are shown in Figure 3 and Figure 4, respectively. The elevations are presented in North American Vertical Datum of 1988 (NAVD 88). In addition, the figures show the inferred general groundwater flow direction in the vicinity of the ATR Complex. In this area, the flow is in a south to southwest direction. The general groundwater flow direction at the INL Site is to the southwest. 
Table 3. Advanced Test Reactor Complex Cold Waste Pond aquifer monitoring well unfiltered and filtered (values are in parentheses) data for the 2011 reporting year.

\begin{tabular}{|c|c|c|c|c|c|c|c|c|c|c|c|}
\hline \multirow{2}{*}{$\begin{array}{c}\text { WELL NAME } \\
\text { Sample Date }\end{array}$} & \multicolumn{2}{|c|}{$\begin{array}{c}\text { USGS-065 } \\
(\mathrm{GW}-016102)\end{array}$} & \multicolumn{2}{|c|}{$\begin{array}{c}\text { TRA-07 } \\
(\mathrm{GW}-016103)\end{array}$} & \multicolumn{2}{|c|}{$\begin{array}{c}\text { USGS-076 } \\
(\mathrm{GW}-016104)\end{array}$} & \multicolumn{2}{|c|}{$\begin{array}{c}\text { TRA-08 } \\
(\mathrm{GW}-016105)\end{array}$} & \multicolumn{2}{|c|}{$\begin{array}{l}\text { Middle-1823 } \\
(\mathrm{GW}-016106)\end{array}$} & \multirow[t]{2}{*}{$\mathrm{PCS} / \mathrm{SCS}^{\mathrm{a}}$} \\
\hline & $04 / 06 / 11$ & $10 / 11 / 11$ & $04 / 06 / 11$ & $10 / 12 / 11$ & $04 / 05 / 11$ & $10 / 12 / 11$ & $04 / 06 / 11$ & $10 / 11 / 11$ & $04 / 05 / 11$ & $10 / 12 / 11$ & \\
\hline $\begin{array}{l}\text { Water Table } \\
\text { Depth (ft below } \\
\text { ground surface) }\end{array}$ & 475.84 & 475.2 & 483.88 & 483.87 & 482.78 & 483.12 & 488.85 & 488.71 & 492.5 & 492.8 & $\mathrm{NA}^{\mathrm{b}}$ \\
\hline $\begin{array}{l}\text { Water Table } \\
\text { Elevation } \\
\text { (above mean sea } \\
\text { level in } \mathrm{ft})^{\mathrm{c}}\end{array}$ & 4452.68 & 4453.32 & 4451.2 & 4451.21 & 4450.43 & 4450.09 & 4449.59 & 4449.73 & 4450.37 & 4450.07 & NA \\
\hline $\mathrm{pH}$ & 8.1 & 8.13 & 8.18 & 7.97 & 8.05 & 7.94 & 8.03 & 8.1 & 8.08 & 8.02 & 6.5 to 8.5 \\
\hline $\begin{array}{l}\text { Total Kjeldahl } \\
\text { nitrogen }(\mathrm{mg} / \mathrm{L})\end{array}$ & 0.129 & $0.1 \mathrm{U}^{\mathrm{d}}$ & 0.141 & 0.253 & $\begin{array}{c}0.147 \\
{[0.1 \mathrm{U}]^{\mathrm{e}}}\end{array}$ & 0.117 & 0.114 & 0.235 & 0.142 & 0.191 & NA \\
\hline $\begin{array}{l}\text { Nitrite nitrogen } \\
(\mathrm{mg} / \mathrm{L})\end{array}$ & $0.05 \mathrm{U}$ & $0.05 \mathrm{U}$ & $0.05 \mathrm{U}$ & $0.05 \mathrm{U}$ & $\begin{array}{c}0.05 \mathrm{U} \\
{[0.05 \mathrm{U}]}\end{array}$ & $0.05 \mathrm{U}$ & $0.05 \mathrm{U}$ & $0.05 \mathrm{U}$ & $0.05 \mathrm{U}$ & $0.05 \mathrm{U}$ & 1 \\
\hline $\begin{array}{l}\text { Nitrate nitrogen } \\
(\mathrm{mg} / \mathrm{L})\end{array}$ & 1.48 & 1.39 & 1.12 & 1.12 & $\begin{array}{c}1.05 \\
{[1.05]}\end{array}$ & 1.06 & 1.02 & 0.975 & 0.985 & 0.935 & 10 \\
\hline $\begin{array}{l}\text { Total nitrogen } \\
(\mathrm{mg} / \mathrm{L})\end{array}$ & 1.634 & 1.465 & 1.286 & 1.398 & $\begin{array}{c}1.222 \\
{[1.125]}\end{array}$ & 1.202 & 1.159 & 1.235 & 1.152 & 1.151 & NA \\
\hline $\begin{array}{l}\text { Total dissolved } \\
\text { solids (mg/L) }\end{array}$ & 439 & 423 & 444 & 432 & $\begin{array}{c}274 \\
{[292]}\end{array}$ & 266 & 289 & 284 & 272 & 263 & 500 \\
\hline $\begin{array}{l}\text { Aluminum } \\
(\mathrm{mg} / \mathrm{L})\end{array}$ & $\begin{array}{c}0.0037 \\
(0.0032)^{\mathrm{g}}\end{array}$ & $\begin{array}{c}0.0082 \\
(0.0037)\end{array}$ & $\begin{array}{c}\mathbf{0 . 5 2 7}^{\mathbf{h}} \\
(0.0054)\end{array}$ & $\begin{array}{c}\mathbf{5 . 6 2 0} \\
(0.0106)\end{array}$ & $\begin{array}{c}0.0035 \\
{[0.0035]} \\
(0.0039) \\
([0.0033])\end{array}$ & $\begin{array}{c}0.0044 \\
(0.0046)\end{array}$ & $\begin{array}{c}1.910 \\
(0.0178)\end{array}$ & $\begin{array}{c}4.270 \\
(0.0183)\end{array}$ & $\begin{array}{c}0.117 \\
(0.0023)\end{array}$ & $\begin{array}{c}0.102 \\
(0.0027)\end{array}$ & 0.2 \\
\hline $\begin{array}{l}\text { Antimony } \\
(\mathrm{mg} / \mathrm{L})\end{array}$ & $0.0004 \mathrm{U}$ & $0.0004 \mathrm{U}$ & $0.0004 \mathrm{U}$ & $0.0004 \mathrm{U}$ & $\begin{array}{c}0.0004 \mathrm{U} \\
{[0.0004 \mathrm{U}]}\end{array}$ & $0.0004 \mathrm{U}$ & $0.0004 \mathrm{U}$ & $0.0004 \mathrm{U}$ & $0.0004 \mathrm{U}$ & $0.0004 \mathrm{U}$ & 0.006 \\
\hline $\begin{array}{l}\text { Arsenic } \\
(\mathrm{mg} / \mathrm{L})\end{array}$ & 0.00061 & $0.0005 \mathrm{U}$ & 0.0006 & 0.0015 & $\begin{array}{c}0.0017 \\
{[0.0013]}\end{array}$ & 0.0014 & 0.0014 & 0.0013 & 0.0019 & 0.0014 & 0.05 \\
\hline $\begin{array}{l}\text { Barium } \\
(\mathrm{mg} / \mathrm{L})\end{array}$ & 0.0437 & 0.0438 & 0.0713 & 0.125 & $\begin{array}{c}0.0693 \\
{[0.0692]}\end{array}$ & 0.0676 & 0.0807 & 0.105 & 0.0614 & 0.0596 & 2 \\
\hline $\begin{array}{l}\text { Cadmium } \\
(\mathrm{mg} / \mathrm{L})\end{array}$ & $0.00025 \mathrm{U}$ & $0.00025 \mathrm{U}$ & $0.00025 \mathrm{U}$ & $0.00025 \mathrm{U}$ & $\begin{array}{c}0.00025 \mathrm{U} \\
{[0.00025 \mathrm{U}]}\end{array}$ & $0.00025 \mathrm{U}$ & $0.00025 \mathrm{U}$ & $0.00025 \mathrm{U}$ & $0.00025 \mathrm{U}$ & $0.00025 \mathrm{U}$ & 0.005 \\
\hline $\begin{array}{l}\text { Chloride } \\
(\mathrm{mg} / \mathrm{L})\end{array}$ & 19.4 & 18.7 & 20.1 & 21.5 & $\begin{array}{c}13.7 \\
{[13.7]}\end{array}$ & 14.8 & 11.7 & 12.3 & 11.6 & 12.1 & 250 \\
\hline
\end{tabular}




\begin{tabular}{|c|c|c|c|c|c|c|c|c|c|c|c|}
\hline \multirow{2}{*}{$\begin{array}{c}\text { WELL NAME } \\
\text { Sample Date }\end{array}$} & \multicolumn{2}{|c|}{$\begin{array}{c}\text { USGS-065 } \\
(\mathrm{GW}-016102)\end{array}$} & \multicolumn{2}{|c|}{$\begin{array}{c}\text { TRA-07 } \\
\text { (GW-016103) }\end{array}$} & \multicolumn{2}{|c|}{$\begin{array}{c}\text { USGS-076 } \\
(\mathrm{GW}-016104)\end{array}$} & \multicolumn{2}{|c|}{$\begin{array}{c}\text { TRA-08 } \\
(\mathrm{GW}-016105)\end{array}$} & \multicolumn{2}{|c|}{$\begin{array}{l}\text { Middle-1823 } \\
(\mathrm{GW}-016106)\end{array}$} & \multirow[t]{2}{*}{$\mathrm{PCS} / \mathrm{SCS}$} \\
\hline & $04 / 06 / 11$ & $10 / 11 / 11$ & $04 / 06 / 11$ & $10 / 12 / 11$ & $04 / 05 / 11$ & $10 / 12 / 11$ & $04 / 06 / 11$ & $10 / 11 / 11$ & $04 / 05 / 11$ & $10 / 12 / 11$ & \\
\hline $\begin{array}{l}\text { Cobalt } \\
(\mathrm{mg} / \mathrm{L})\end{array}$ & $0.0025 \mathrm{U}$ & $0.0025 \mathrm{U}$ & $0.0025 \mathrm{U}$ & $0.0025 \mathrm{U}$ & $\begin{array}{c}0.0025 \mathrm{U} \\
{[0.0025 \mathrm{U}]}\end{array}$ & $0.0025 \mathrm{U}$ & $0.0025 \mathrm{U}$ & $0.0025 \mathrm{U}$ & $0.0025 \mathrm{U}$ & $0.0025 \mathrm{U}$ & NA \\
\hline $\begin{array}{l}\text { Copper } \\
\text { (mg/L) }\end{array}$ & $0.0025 \mathrm{U}$ & $0.0025 \mathrm{U}$ & 0.0302 & 0.0240 & $\begin{array}{c}0.0092 \\
{[0.0146]}\end{array}$ & $0.0025 \mathrm{U}$ & 0.0205 & 0.0092 & 0.104 & $0.0025 \mathrm{U}$ & 1.3 \\
\hline $\begin{array}{l}\text { Fluoride } \\
(\mathrm{mg} / \mathrm{L})\end{array}$ & 0.242 & 0.217 & 0.236 & 0.210 & $\begin{array}{c}0.16 \\
{[0.164]}\end{array}$ & 0.179 & 0.219 & 0.200 & 0.162 & 0.173 & 4 \\
\hline $\begin{array}{l}\text { Iron } \\
(\mathrm{mg} / \mathrm{L})\end{array}$ & $\begin{array}{c}0.050 \mathrm{U} \\
(0.050 \mathrm{U})\end{array}$ & $\begin{array}{c}0.119 \\
(0.0554)\end{array}$ & $\begin{array}{c}\mathbf{0 . 6 5 4} \\
(0.0536)\end{array}$ & $\begin{array}{c}\mathbf{3 . 3 6 0} \\
(0.050 \mathrm{U})\end{array}$ & $\begin{array}{c}0.105 \\
{[0.134]} \\
(0.050 \mathrm{U}) \\
([0.050 \mathrm{U}]) \\
\end{array}$ & $\begin{array}{c}0.050 \mathrm{U} \\
(0.050 \mathrm{U})\end{array}$ & $\begin{array}{c}1.110 \\
(0.050 \mathrm{U})\end{array}$ & $\begin{array}{c}\mathbf{1 . 5 4 0} \\
(0.050 \mathrm{U})\end{array}$ & $\begin{array}{c}0.0946 \\
(0.050 \mathrm{U})\end{array}$ & $\begin{array}{c}0.050 \mathrm{U} \\
(0.050 \mathrm{U})\end{array}$ & 0.3 \\
\hline $\begin{array}{l}\text { Manganese } \\
(\mathrm{mg} / \mathrm{L})\end{array}$ & $\begin{array}{c}0.0025 \mathrm{U} \\
(0.0025 \mathrm{U})\end{array}$ & $\begin{array}{c}0.0025 \mathrm{U} \\
(0.0025 \mathrm{U})\end{array}$ & $\begin{array}{l}0.0091 \\
(0.006)\end{array}$ & $\begin{array}{c}\mathbf{0 . 0 5 0 8} \\
(0.0025 \mathrm{U})\end{array}$ & $\begin{array}{c}0.0025 \mathrm{U} \\
{[0.0025 \mathrm{U}]} \\
(0.0025 \mathrm{U}) \\
([0.0025 \mathrm{U}])\end{array}$ & $\begin{array}{c}0.0025 \mathrm{U} \\
(0.0025 \mathrm{U})\end{array}$ & $\begin{array}{c}0.020 \\
(0.0025 \mathrm{U})\end{array}$ & $\begin{array}{c}0.0309 \\
(0.0025 \mathrm{U})\end{array}$ & $\begin{array}{c}0.0032 \\
(0.0075)\end{array}$ & $\begin{array}{c}0.0032 \\
(0.0025 \mathrm{U})\end{array}$ & 0.05 \\
\hline $\begin{array}{l}\text { Mercury } \\
(\mathrm{mg} / \mathrm{L})\end{array}$ & $0.0002 \mathrm{U}$ & $0.0002 \mathrm{U}$ & $0.0002 \mathrm{U}$ & $0.0002 \mathrm{U}$ & $\begin{array}{c}0.0002 \mathrm{U} \\
{[0.0002 \mathrm{U}]}\end{array}$ & $0.0002 \mathrm{U}$ & $0.0002 \mathrm{U}$ & $0.0002 \mathrm{U}$ & $0.0002 \mathrm{U}$ & $0.0002 \mathrm{U}$ & 0.002 \\
\hline $\begin{array}{l}\text { Selenium } \\
(\mathrm{mg} / \mathrm{L})\end{array}$ & 0.0016 & 0.0020 & 0.0011 & 0.0019 & $\begin{array}{c}0.0012 \\
{[0.0012]}\end{array}$ & 0.0014 & 0.00086 & 0.0013 & 0.0011 & 0.0014 & 0.05 \\
\hline $\begin{array}{l}\text { Silver } \\
(\mathrm{mg} / \mathrm{L})\end{array}$ & $\begin{array}{c}0.005 \mathrm{U} \\
(0.005 \mathrm{U})\end{array}$ & $\begin{array}{c}0.005 \mathrm{U} \\
(0.005 \mathrm{U})\end{array}$ & $\begin{array}{c}0.005 \mathrm{U} \\
(0.005 \mathrm{U})\end{array}$ & $\begin{array}{c}0.005 \mathrm{U} \\
(0.005 \mathrm{U})\end{array}$ & $\begin{array}{c}0.005 \mathrm{U} \\
{[0.005 \mathrm{U}]} \\
(0.005 \mathrm{U}) \\
([0.005 \mathrm{U}]) \\
\end{array}$ & $\begin{array}{c}0.005 \mathrm{U} \\
(0.005 \mathrm{U})\end{array}$ & $\begin{array}{c}0.005 \mathrm{U} \\
(0.005 \mathrm{U})\end{array}$ & $\begin{array}{c}0.005 \mathrm{U} \\
(0.005 \mathrm{U})\end{array}$ & $\begin{array}{c}0.005 \mathrm{U} \\
(0.005 \mathrm{U})\end{array}$ & $\begin{array}{c}0.005 \mathrm{U} \\
(0.005 \mathrm{U})\end{array}$ & 0.1 \\
\hline $\begin{array}{l}\text { Sulfate } \\
(\mathrm{mg} / \mathrm{L})\end{array}$ & 160 & 162 & 154 & 158 & $\begin{array}{c}32.3 \\
{[32.7]}\end{array}$ & 32.8 & 49.9 & 49.7 & 34.4 & 34.6 & 250 \\
\hline \multicolumn{12}{|c|}{ 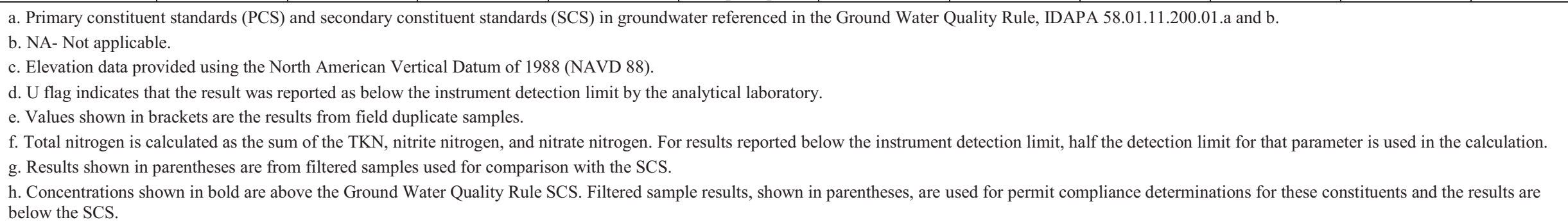 } \\
\hline
\end{tabular}




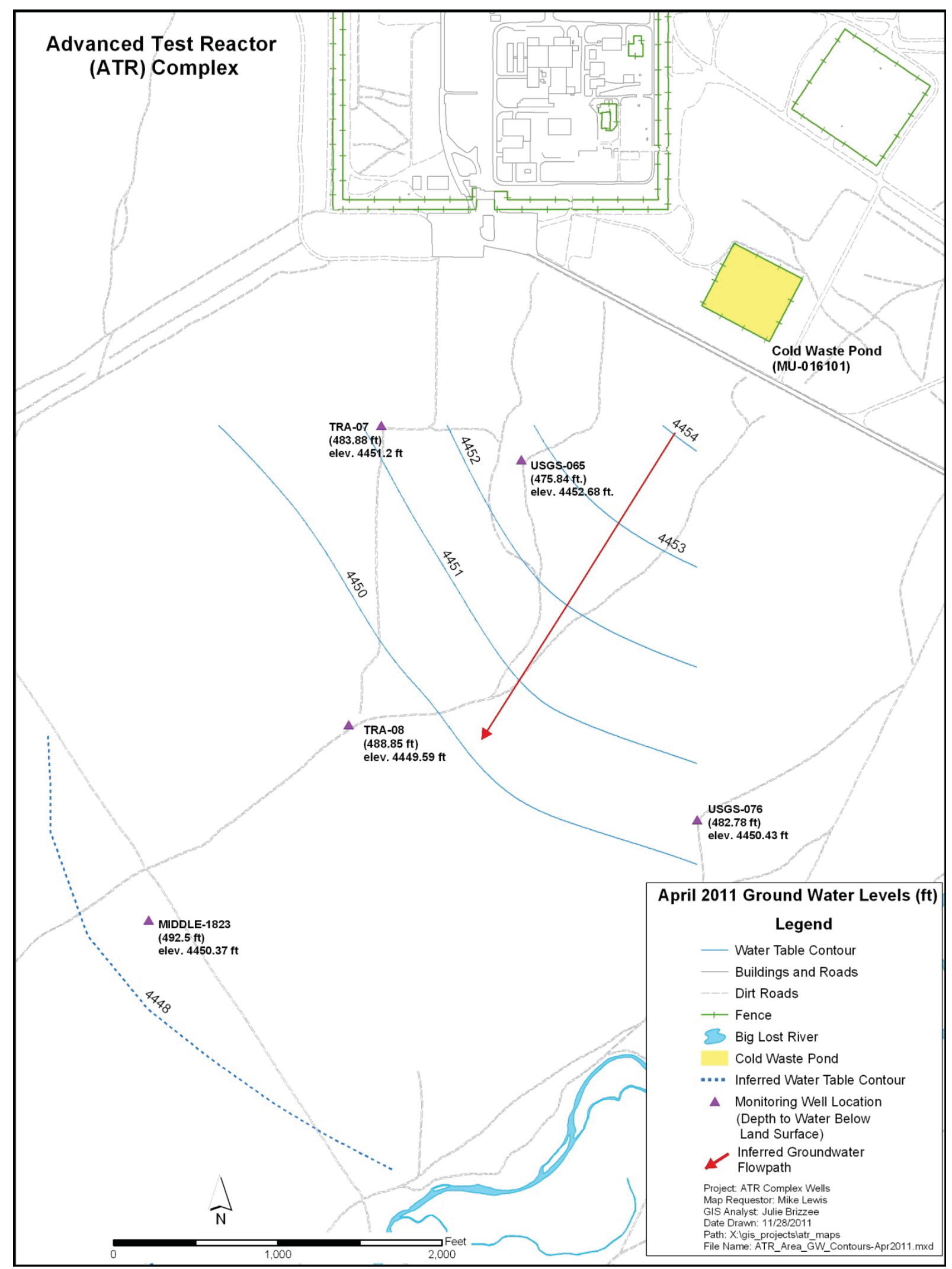

Figure 3. Groundwater contour map based on the April 2011 water level measurements. 


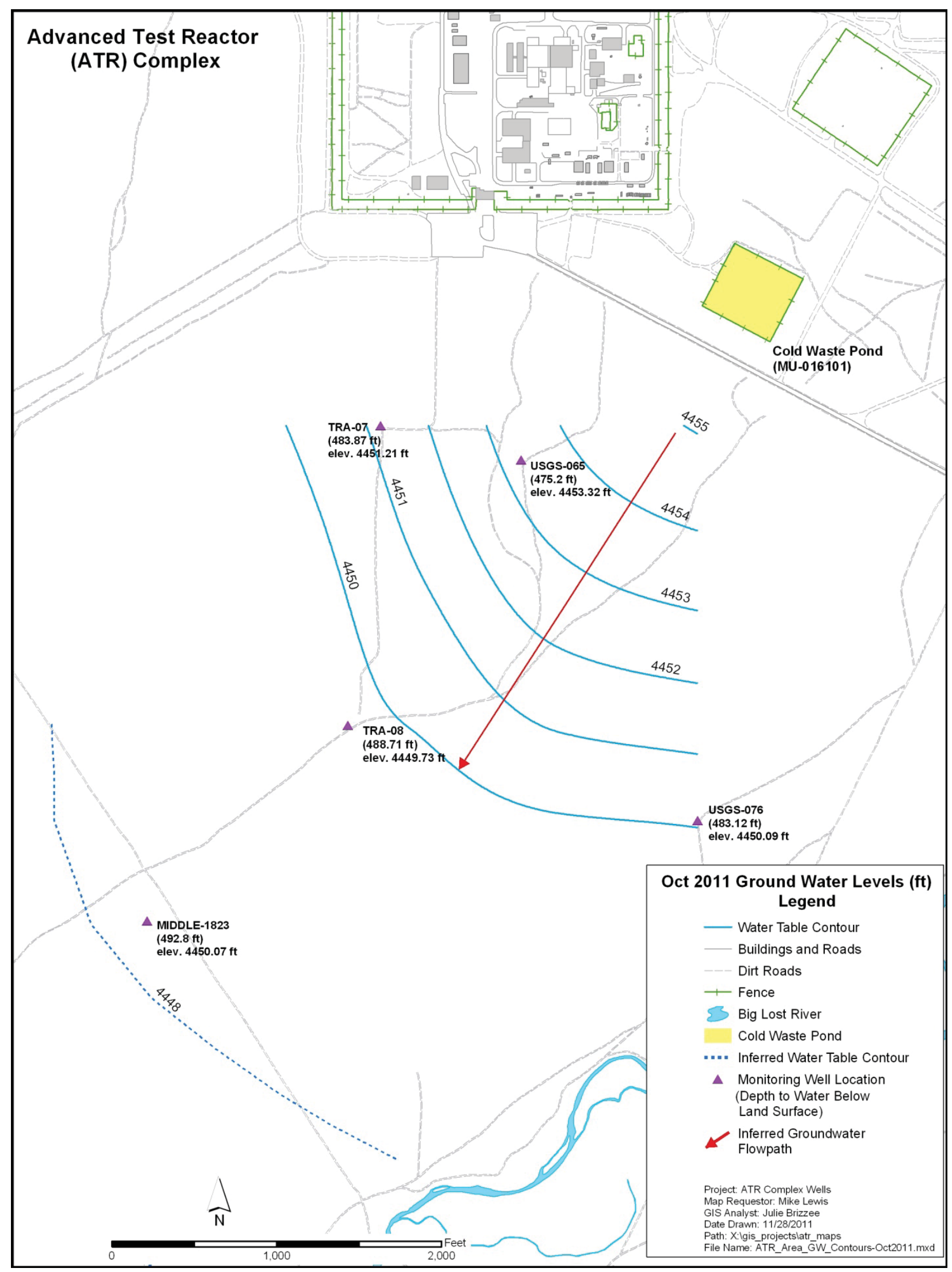

Figure 4. Groundwater contour map based on the October 2011 water level measurements. 


\section{PERMIT YEAR SUMMARIES}

This section provides information and status associated with permit required compliance activities. Noncompliance issues are also addressed in this section. Section 5.3 identifies issues that were not considered noncompliances but were not typical operational or reporting events.

\subsection{Status of Permit Required Compliance Activity}

Section E of the current ATR Complex IWRP identified one compliance activity and specified the completion date. This compliance activity was reported as complete in the 2009 Annual Report.

\subsection{Noncompliance Issues}

Decommissioning and demolition activities were being performed that required replacement of affected electrical systems providing power to the ATR Complex CWP system. As a result, a power outage occurred that resulted in the flow totalizer being without power for a period of approximately 6 hours and 20 minutes. Due to the outage, the flow for July 20, 2011, is an estimated value. Flow rate before the outage was $85 \mathrm{gpm}$ and $79 \mathrm{gpm}$ after the outage. The flow rate of $85 \mathrm{gpm}$ was used to calculate the volume during the outage and resulted in an estimated volume of 32,300 gallons (380 minutes $\mathrm{x}$ $85 \mathrm{gpm}$ ). Adding the estimated volume to the recorded volume gave a total daily volume of 141,580 gallons.

Because of potential noncompliance issues as a result of the decommissioning and demolition activities, a 30-day notice pursuant to the IWRP standard permit condition, Section I.7.b, was submitted (Stenzel 2011). No other noncompliance issues, other than estimating the flow volume were identified.

In accordance with the August 4, 2010, DEQ letter (Rackow 2010a), a copy of the daily log sheet is included at the end of Appendix A daily flow readings. The log sheet identifies the approach for estimating the flow volume.

\subsection{Other Issues}

This section discusses other issues for the ATR Complex Cold Waste system that occurred during the permit year. There was only one issue identified for the 2011 permit year.

\subsubsection{Incorrect Report Information}

A project to deepen aquifer monitoring well TRA-08 (GW-016105) was completed on April 21, 2010. Information concerning this project was reported in the 2010 Annual Report and included a diagram of the modified well. The well diagram was provided to BEA by another contractor. On May 10, 2011, BEA received the transmittal of the contractor's Water Use and Comprehensive Well Inventory Information, which included a revised well diagram for well TRA-08. BEA identified minor changes in the revised well diagram from the one previously provided in the 2010 Annual Report.

In accordance with Section I.7.e of the IWRP for reporting incorrect information found in a report, a letter identifying the corrected information and providing a copy of the revised well diagram was submitted to the DEQ on May 23, 2011 (Stenzel 2011a).

\section{ENVIRONMENTAL IMPACTS}

The IWRP allows $300 \mathrm{MG} /$ year as a five year annual average, not to exceed $375 \mathrm{MG}$ annually. The total volume discharged to the CWP for this period (November 1, 2010, through October 31, 2011) was 165.57 MG. The average daily flow during the 2011 permit year was 453,620 gallons. No runoff occurred from the application area. 
High effluent concentrations of TSS have the potential to reduce the infiltration capacity of the soil. Section F of the IWRP specifies a TSS effluent limit of $100 \mathrm{mg} / \mathrm{L}$. All effluent monthly TSS concentrations were below the laboratory instrument detection limit of $4 \mathrm{mg} / \mathrm{L}$ (see Table 1). No negative impacts to the soil infiltration capacity from TSS loading are expected.

The IWRP effluent limit for TN is $20 \mathrm{mg} / \mathrm{L}$. The monthly effluent TN concentrations were below the permit limit ranging from $1.051 \mathrm{mg} / \mathrm{L}$ to $3.366 \mathrm{mg} / \mathrm{L}$ (see Table 1). Nitrogen can be lost or removed from the soil by leaching, ammonia volatilization, and denitrification. Total nitrogen in the nearest down gradient well (USGS-065) from the CWP was $1.634 \mathrm{mg} / \mathrm{L}$ and $1.415 \mathrm{mg} / \mathrm{L}$ in the April and October 2011 samples, respectively (see Table 3). Although there is not a groundwater quality standard for TN, there is a standard for nitrate $(10 \mathrm{mg} / \mathrm{L})$ and nitrite $(1 \mathrm{mg} / \mathrm{L})$. The April 2011 nitrate sample results were slightly higher than the October 2011 results from well USGS-065. The April 2011 sample results from well USGS-065 had a nitrate concentration of $1.48 \mathrm{mg} / \mathrm{L}$ and a nitrite concentration of less than $0.05 \mathrm{mg} / \mathrm{L}$ (undetected). Both were significantly less than their respective groundwater quality standards.

Sulfate and TDS concentrations (see Table 1) in the effluent have the potential to impact groundwater. Sulfate has high solubility and tends to move at a similar velocity as the groundwater (DEQ 2007). Sulfate concentrations in the 2011 permit year effluent monthly samples ranged from a low of $21.2 \mathrm{mg} / \mathrm{L}$ to a high of $526 \mathrm{mg} / \mathrm{L}$. The TDS concentrations ranged from a low of $241 \mathrm{mg} / \mathrm{L}$ to a high of $1,060 \mathrm{mg} / \mathrm{L}$. There are no IWRP effluent limits for sulfate and TDS. However, there are groundwater quality standards for these two parameters.

Monitoring well USGS-065 and TRA-07 are located southwest of the CWP. Both wells show similar elevated levels of sulfate and TDS in the April and October 2011 samples. The SCS for sulfate and TDS are $250 \mathrm{mg} / \mathrm{L}$ and $500 \mathrm{mg} / \mathrm{L}$, respectively. Maximum sulfate concentrations in USGS-065 and TRA-07 were $162 \mathrm{mg} / \mathrm{L}$ and $158 \mathrm{mg} / \mathrm{L}$, respectively. The maximum TDS concentration for well USGS-065 was $439 \mathrm{mg} / \mathrm{L}$ in the April 2011 sample. Well TRA-07 had a maximum TDS concentration of $444 \mathrm{mg} / \mathrm{L}$ in the April 2011 sample. The 2011 sulfate and TDS results were similar to the April and October 2010 sulfate and TDS concentrations in these wells. The maximum 2010 sulfate concentration in well USGS-065 was $160 \mathrm{mg} / \mathrm{L}$ and $155 \mathrm{mg} / \mathrm{L}$ in well TRA-07. The maximum 2010 TDS concentration in well USGS-065 was $437 \mathrm{mg} / \mathrm{L}$ and $443 \mathrm{mg} / \mathrm{L}$ in well TRA-07. When compared with the 2009 and 2010 sample results for wells USGS-065 and TRA-07, it appears the sulfate and TDS concentrations have stabilized, at least temporarily.

Elevated sulfate and TDS concentrations in the groundwater can be seen near the CWP, which quickly dissipates with distance from the pond. This can be seen when comparing the sulfate and TDS concentrations found in well USGS-065 and Middle-1823. Well Middle-1823, located approximately 4,000 ft down gradient from the CWP had a maximum 2011 sulfate and TDS concentration of $34.6 \mathrm{mg} / \mathrm{L}$ and $272 \mathrm{mg} / \mathrm{L}$, respectively. Well USGS-065, located approximately 1,200 ft down gradient of the CWP had a maximum 2011 sulfate concentration of $162 \mathrm{mg} / \mathrm{L}$ and a TDS concentration of $439 \mathrm{mg} / \mathrm{L}$. The concentrations of sulfate and TDS in well Middle-1823 are similar to the concentrations in the up/cross gradient well USGS-076.

As stated above, sulfate and TDS have SCSs for groundwater quality. The SCSs are generally based on aesthetic qualities including odor, taste, color, and foaming (EPA 1992). Sulfate is listed for causing a "salty taste" in drinking water. Total dissolved solids are listed for "hardness deposits, colored water, staining, and salty taste." The nearest drinking water well is located approximately three miles down gradient of the CWP. Since the higher level of contaminants remain, and are expected to continue to remain localized near the CWP and since they are regulated because of their aesthetic qualities, impacts to human health and the environment are expected to be minimal.

The April and October 2011 unfiltered sample results for Al and Fe in wells TRA-07 and TRA-08 were above their respective SCSs, whereas, the filtered (used for permit compliance) sample results for these two metals were all below the SCS (see Table 4). The unfiltered October manganese result for well 
TRA-07 was slightly above the SCS. All other April and October filtered and unfiltered manganese sample results for wells TRA-07 and TRA-08 were below the SCS.

Table 4. Comparison of 2011 results from unfiltered and filtered (values are in parentheses) samples collected from wells TRA-07 and TRA-08.

\begin{tabular}{|c|c|c|c|c|c|}
\hline \multirow{2}{*}{$\begin{array}{l}\text { WELL NAME } \\
\text { Sample Date }\end{array}$} & \multicolumn{2}{|c|}{$\begin{array}{c}\text { TRA-07 } \\
(\mathrm{GW}-016103)\end{array}$} & \multicolumn{2}{|c|}{$\begin{array}{c}\text { TRA-08 } \\
(\mathrm{GW}-016105)\end{array}$} & \multirow[t]{2}{*}{$\mathrm{SCS}^{\mathrm{a}}$} \\
\hline & $04 / 06 / 11$ & $10 / 12 / 11$ & 04/06/11 & 10/11/11 & \\
\hline Aluminum (mg/L) & $\begin{array}{c}\mathbf{0 . 5 2 7} \\
(0.0054)^{\mathrm{c}}\end{array}$ & $\begin{array}{c}\mathbf{5 . 6 2 0} \\
(0.0106)\end{array}$ & $\begin{array}{c}1.910 \\
(0.0178)\end{array}$ & $\begin{array}{c}4.270 \\
(0.0183)\end{array}$ & 0.2 \\
\hline Iron $(\mathrm{mg} / \mathrm{L})$ & $\begin{array}{c}\mathbf{0 . 6 5 4} \\
(0.0536)\end{array}$ & $\begin{array}{c}3.360 \\
\left(0.050 \mathrm{U}^{\mathrm{d}}\right)\end{array}$ & $\begin{array}{c}1.110 \\
(0.050 \mathrm{U})\end{array}$ & $\begin{array}{c}1.540 \\
(0.050 \mathrm{U})\end{array}$ & 0.3 \\
\hline Manganese $(\mathrm{mg} / \mathrm{L})$ & $\begin{array}{l}0.0091 \\
(0.006)\end{array}$ & $\begin{array}{c}\mathbf{0 . 0 5 0 8} \\
(0.0025 \mathrm{U})\end{array}$ & $\begin{array}{c}0.020 \\
(0.0025 \mathrm{U})\end{array}$ & $\begin{array}{c}0.0309 \\
(0.0025 \mathrm{U})\end{array}$ & 0.05 \\
\hline \multicolumn{6}{|c|}{$\begin{array}{l}\text { a. Secondary constituent standards (SCS) in groundwater referenced in the Ground Water Quality Rule, IDAPA 58.01.11.200.01.b. } \\
\text { b. Concentrations shown in bold are above the Ground Water Quality Rule SCS. } \\
\text { c. Results shown in parentheses are from filtered samples and are used for permit compliance determination with SCS. } \\
\text { d. U flag indicates that the result was reported as below the instrument detection limit by the analytical laboratory. }\end{array}$} \\
\hline
\end{tabular}

Concentrations of $\mathrm{Al}, \mathrm{Fe}$, and $\mathrm{Mn}$ in samples from the effluent to the CWP and from well USGS-065 indicate that discharges to the CWP are not expected to be the direct cause of the high Al, Fe, and Mn in wells TRA-07 and TRA-08. It is likely that the higher concentrations of these metals in wells TRA-07 and TRA-08 are due to suspended solids found within the well. The high levels of metals appear to be confined to wells TRA-07 and TRA-08 since the concentrations of these metals in the other two down gradient wells (USGS-065 and Middle-1823) were at low levels or below the laboratory instrument detection limits (see Table 3).

All three metals have an impact on color of the water. Both iron and manganese cause staining and also cause the water to have a metallic taste. However, similar to the sulfate and TDS concentrations in the groundwater near the CWP, impacts to human health and the environment from concentrations of $\mathrm{Al}$, $\mathrm{Fe}$, and $\mathrm{Mn}$ in wells TRA-07 and TRA-08 are expected to be minimal.

There are positive impacts to the environment associated with the operation of the CWP. These include returning a significant portion of the industrial wastewater to the aquifer and providing needed water for several native animal species in an otherwise arid environment. 


\section{REFERENCES}

40 CFR 136, "Guidelines Establishing Test Procedures for the Analysis of Pollutants," Code of Federal Regulations, Office of the Federal Register.

40 CFR 141, "National Primary Drinking Water Regulations," Code of Federal Regulations, Office of the Federal Register.

40 CFR 143, "National Secondary Drinking Water Regulations," Code of Federal Regulations, Office of the Federal Register.

DEQ, 2007, Guidance for Reclamation and Reuse of Municipal and Industrial Wastewater, Idaho Department of Environmental Quality, September 2007.

Eager, G., P.E., DEQ, to W. F. Hamel, DOE-ID, August 20, 2008, "Minor Modification “B”, Facility Name Change from Reactor Technology Complex (RTC) to Advanced Test Reactor Complex (ATR Complex), Cold Waste Pond, Wastewater Reuse Permit No. LA-000161-01," CCN 214687.

Environmental Protection Agency, 1992, Secondary Drinking Water Regulations: Guidance for Nuisance Chemicals, EPA 810/K-92-001.

IDAPA 58.01.11, "Ground Water Quality Rule.”

Johnston, J., DEQ, to W. F. Hamel, DOE-ID, February 26, 2008, "Reactor Technology Complex (RTC) Cold Waste Pond, Wastewater Reuse Permit No. LA-000161-01 (Industrial Wastewater)," CCN 212842.

Rackow, T., P.E., DEQ, to J. A. Stenzel, INL, January 29, 2010, “LA-000161-01 ATR Cold Waste Pond Permit Modification Request", CCN 219974.

Rackow, T., P.E., DEQ, to T. L. Carlson, INL, August 4, 2010a, "Clarification of Flow Reporting Requirements, Wastewater Reuse Permits: LA-000161-01, INL ATR Complex Cold Waste Pond, Issued February 26, 2008, LA-000141-03, INL CFA Sewage Treatment Plant, Issued March 17, 2010, and LA-000160-01, INL MFC Industrial Waste Pond, Effective May 1, 2010," CCN 221858.

Rackow, T., P.E., DEQ, to J. A. Stenzel, INL, June 10, 2011a, "LA-000161-01 INL ATR Cold Waste Ponds, 2010 Annual Report Review”, CCN 224459.

Rackow, T., P.E., DEQ, to J. A. Stenzel, INL, August 12, 2011b, “LA-000161-01 INL ATR, 2011 Wastewater Reuse Inspection", CCN 225075.

Stenzel, J. A., INL, to G. Eager, P.E., DEQ, October 8, 2009, "Request to Use Dissolved Concentrations of Secondary Constituents for Compliance Groundwater Monitoring," CCN 218748.

Stenzel, J. A., INL, to T. Rackow, P.E., DEQ, March 3, 2011, “Thirty-Day Notice for Industrial Wastewater Reuse Permit No. LA-000161-01, Minor Modification B-Advanced Test Reactor Complex Cold Waste Pond," CCN 223487.

Stenzel, J. A., INL, to G. Eager, P.E., DEQ and R. Huddleston, P.E., DEQ, May 23, 2011a, "Revised Well TRA-08 Construction Information for the 2010 Annual Industrial Wastewater Reuse Report for the Idaho National Laboratory Site's Advanced Test Reactor Complex Cold Waste Pond," CCN 224211. 
Appendix A

\section{Daily Discharge Volumes to the Advanced Test Reactor Complex Cold Waste Pond}




\section{Appendix A}

\section{Daily Discharge Volumes to the Advanced Test Reactor Complex Cold Waste Pond}

Table A-1. Daily discharge volumes to the ATR Complex CWP for the 2011 permit year.

\begin{tabular}{|c|c|}
\hline Date & $\begin{array}{c}\text { Daily Discharge } \\
\text { Volume (gallons) }\end{array}$ \\
\hline $11 / 01 / 2010$ & 760,000 \\
\hline $11 / 02 / 2010$ & 534,700 \\
\hline $11 / 03 / 2010$ & 566,100 \\
\hline $11 / 04 / 2010$ & 633,670 \\
\hline $11 / 05 / 2010$ & 668,770 \\
\hline $11 / 06 / 2010$ & 566,140 \\
\hline $11 / 07 / 2010$ & 640,000 \\
\hline $11 / 08 / 2010$ & 516,700 \\
\hline $11 / 09 / 2010$ & 601,470 \\
\hline $11 / 10 / 2010$ & 602,380 \\
\hline $11 / 11 / 2010$ & 692,280 \\
\hline $11 / 12 / 2010$ & 608,970 \\
\hline $11 / 13 / 2010$ & 528,300 \\
\hline $11 / 14 / 2010$ & 780,000 \\
\hline $11 / 15 / 2010$ & 453,050 \\
\hline $11 / 16 / 2010$ & 635,000 \\
\hline $11 / 17 / 2010$ & 323,480 \\
\hline $11 / 18 / 2010$ & 188,920 \\
\hline $11 / 19 / 2010$ & 176,550 \\
\hline $11 / 20 / 2010$ & 280,450 \\
\hline $11 / 21 / 2010$ & 238,460 \\
\hline $11 / 22 / 2010$ & 316,890 \\
\hline $11 / 23 / 2010$ & 234,610 \\
\hline $11 / 24 / 2010$ & 278,700 \\
\hline $11 / 25 / 2010$ & 296,120 \\
\hline $11 / 26 / 2010$ & 334,500 \\
\hline $11 / 27 / 2010$ & 162,700 \\
\hline $11 / 28 / 2010$ & 221,700 \\
\hline $11 / 29 / 2010$ & 235,920 \\
\hline $11 / 30 / 2010$ & 301,000 \\
\hline $12 / 01 / 2010$ & 230,650 \\
\hline $12 / 02 / 2010$ & 261,620 \\
\hline $12 / 03 / 2010$ & 288,910 \\
\hline
\end{tabular}

\begin{tabular}{|c|c|}
\hline Date & $\begin{array}{c}\text { Daily Discharge } \\
\text { Volume (gallons) }\end{array}$ \\
\hline $12 / 04 / 2010$ & 255,240 \\
\hline $12 / 05 / 2010$ & 218,300 \\
\hline $12 / 06 / 2010$ & 262,650 \\
\hline $12 / 07 / 2010$ & 302,000 \\
\hline $12 / 08 / 2010$ & 213,000 \\
\hline $12 / 09 / 2010$ & 291,770 \\
\hline $12 / 10 / 2010$ & 236,300 \\
\hline $12 / 11 / 2010$ & 309,740 \\
\hline $12 / 12 / 2010$ & 198,960 \\
\hline $12 / 13 / 2010$ & 261,920 \\
\hline $12 / 14 / 2010$ & 314,320 \\
\hline $12 / 15 / 2010$ & 244,320 \\
\hline $12 / 16 / 2010$ & 261,660 \\
\hline $12 / 17 / 2010$ & 259,530 \\
\hline $12 / 18 / 2010$ & 257,400 \\
\hline $12 / 19 / 2010$ & 312,000 \\
\hline $12 / 20 / 2010$ & 250,340 \\
\hline $12 / 21 / 2010$ & 238,190 \\
\hline $12 / 22 / 2010$ & 273,750 \\
\hline $12 / 23 / 2010$ & 266,460 \\
\hline $12 / 24 / 2010$ & 271,700 \\
\hline $12 / 25 / 2010$ & 250,540 \\
\hline $12 / 26 / 2010$ & 266,410 \\
\hline $12 / 27 / 2010$ & 274,180 \\
\hline $12 / 28 / 2010$ & 259,860 \\
\hline $12 / 29 / 2010$ & 240,410 \\
\hline $12 / 30 / 2010$ & 242,100 \\
\hline $12 / 31 / 2010$ & 275,240 \\
\hline $01 / 01 / 2011$ & 257,610 \\
\hline $01 / 02 / 2011$ & 304,900 \\
\hline $01 / 03 / 2011$ & 201,230 \\
\hline $01 / 04 / 2011$ & 293,000 \\
\hline $01 / 05 / 2011$ & 217,290 \\
\hline
\end{tabular}




\begin{tabular}{|c|c|}
\hline Date & $\begin{array}{c}\text { Daily Discharge } \\
\text { Volume (gallons) }\end{array}$ \\
\hline $01 / 06 / 2011$ & 262,060 \\
\hline $01 / 07 / 2011$ & 253,550 \\
\hline $01 / 08 / 2011$ & 622,450 \\
\hline $01 / 09 / 2011$ & 581,770 \\
\hline $01 / 10 / 2011$ & 761,840 \\
\hline $01 / 11 / 2011$ & 579,070 \\
\hline $01 / 12 / 2011$ & 469,710 \\
\hline $01 / 13 / 2011$ & 628,240 \\
\hline $01 / 14 / 2011$ & 573,030 \\
\hline $01 / 15 / 2011$ & 665,540 \\
\hline $01 / 16 / 2011$ & 559,110 \\
\hline $01 / 17 / 2011$ & 633,930 \\
\hline $01 / 18 / 2011$ & 612,450 \\
\hline $01 / 19 / 2011$ & 584,510 \\
\hline $01 / 20 / 2011$ & 685,990 \\
\hline $01 / 21 / 2011$ & 611,990 \\
\hline $01 / 22 / 2011$ & 609,190 \\
\hline $01 / 23 / 2011$ & 525,810 \\
\hline $01 / 24 / 2011$ & 596,240 \\
\hline $01 / 25 / 2011$ & 713,000 \\
\hline $01 / 26 / 2011$ & 591,300 \\
\hline $01 / 27 / 2011$ & 578,520 \\
\hline $01 / 28 / 2011$ & 614,990 \\
\hline $01 / 29 / 2011$ & 661,020 \\
\hline $01 / 30 / 2011$ & 691,170 \\
\hline $01 / 31 / 2011$ & 690,000 \\
\hline $02 / 01 / 2011$ & 591,000 \\
\hline $02 / 02 / 2011$ & 530,520 \\
\hline $02 / 03 / 2011$ & 554,000 \\
\hline $02 / 04 / 2011$ & 596,730 \\
\hline $02 / 05 / 2011$ & 674,540 \\
\hline $02 / 06 / 2011$ & 544,850 \\
\hline $02 / 07 / 2011$ & 666,000 \\
\hline $02 / 08 / 2011$ & 485,500 \\
\hline $02 / 09 / 2011$ & 608,450 \\
\hline $02 / 10 / 2011$ & 582,160 \\
\hline $02 / 11 / 2011$ & 585,710 \\
\hline $02 / 12 / 2011$ & 710,130 \\
\hline $02 / 13 / 2011$ & 456,190 \\
\hline
\end{tabular}

\begin{tabular}{|c|c|}
\hline Date & $\begin{array}{c}\text { Daily Discharge } \\
\text { Volume (gallons) }\end{array}$ \\
\hline $02 / 14 / 2011$ & 724,120 \\
\hline $02 / 15 / 2011$ & 518,210 \\
\hline $02 / 16 / 2011$ & 571,810 \\
\hline $02 / 17 / 2011$ & 746,200 \\
\hline $02 / 18 / 2011$ & 455,960 \\
\hline $02 / 19 / 2011$ & 629,410 \\
\hline $02 / 20 / 2011$ & 562,700 \\
\hline $02 / 21 / 2011$ & 586,010 \\
\hline $02 / 22 / 2011$ & 661,660 \\
\hline $02 / 23 / 2011$ & 670,000 \\
\hline $02 / 24 / 2011$ & 758,840 \\
\hline $02 / 25 / 2011$ & 818,600 \\
\hline $02 / 26 / 2011$ & 620,070 \\
\hline $02 / 27 / 2011$ & 861,020 \\
\hline $02 / 28 / 2011$ & 880,000 \\
\hline $03 / 01 / 2011$ & 739,700 \\
\hline $03 / 02 / 2011$ & 638,000 \\
\hline $03 / 03 / 2011$ & 697,910 \\
\hline $03 / 04 / 2011$ & 640,600 \\
\hline $03 / 05 / 2011$ & 888,010 \\
\hline $03 / 06 / 2011$ & 670,280 \\
\hline $03 / 07 / 2011$ & 760,000 \\
\hline $03 / 08 / 2011$ & 547,000 \\
\hline $03 / 09 / 2011$ & 631,000 \\
\hline $03 / 10 / 2011$ & 641,630 \\
\hline $03 / 11 / 2011$ & 672,960 \\
\hline $03 / 12 / 2011$ & 650,750 \\
\hline $03 / 13 / 2011$ & 840,000 \\
\hline $03 / 14 / 2011$ & 538,320 \\
\hline $03 / 15 / 2011$ & 695,830 \\
\hline $03 / 16 / 2011$ & 659,050 \\
\hline $03 / 17 / 2011$ & 678,700 \\
\hline $03 / 18 / 2011$ & 658,440 \\
\hline $03 / 19 / 2011$ & 686,500 \\
\hline $03 / 20 / 2011$ & 735,000 \\
\hline $03 / 21 / 2011$ & 637,920 \\
\hline $03 / 22 / 2011$ & 662,010 \\
\hline $03 / 23 / 2011$ & 651,570 \\
\hline $03 / 24 / 2011$ & 694,230 \\
\hline
\end{tabular}




\begin{tabular}{|c|c|}
\hline Date & $\begin{array}{l}\text { Daily Discharge } \\
\text { Volume (gallons) }\end{array}$ \\
\hline $03 / 25 / 2011$ & 601,010 \\
\hline $03 / 26 / 2011$ & 743,580 \\
\hline $03 / 27 / 2011$ & 827,000 \\
\hline $03 / 28 / 2011$ & 544,710 \\
\hline $03 / 29 / 2011$ & 810,000 \\
\hline $03 / 30 / 2011$ & 832,140 \\
\hline $03 / 31 / 2011$ & 954,430 \\
\hline $04 / 01 / 2011$ & $1,038,490$ \\
\hline $04 / 02 / 2011$ & 605,340 \\
\hline $04 / 03 / 2011$ & 674,070 \\
\hline $04 / 04 / 2011$ & 692,310 \\
\hline $04 / 05 / 2011$ & 850,700 \\
\hline $04 / 06 / 2011$ & 600,080 \\
\hline $04 / 07 / 2011$ & 623,500 \\
\hline $04 / 08 / 2011$ & 645,530 \\
\hline $04 / 09 / 2011$ & 756,000 \\
\hline $04 / 10 / 2011$ & 722,470 \\
\hline $04 / 11 / 2011$ & 820,000 \\
\hline $04 / 12 / 2011$ & 630,080 \\
\hline $04 / 13 / 2011$ & 685,950 \\
\hline $04 / 14 / 2011$ & 467,210 \\
\hline $04 / 15 / 2011$ & 295,600 \\
\hline $04 / 16 / 2011$ & 267,760 \\
\hline $04 / 17 / 2011$ & 360,000 \\
\hline $04 / 18 / 2011$ & 241,700 \\
\hline $04 / 19 / 2011$ & 352,710 \\
\hline $04 / 20 / 2011$ & 353,350 \\
\hline $04 / 21 / 2011$ & 422,180 \\
\hline $04 / 22 / 2011$ & 279,860 \\
\hline $04 / 23 / 2011$ & 410,140 \\
\hline $04 / 24 / 2011$ & 330,000 \\
\hline $04 / 25 / 2011$ & 286,340 \\
\hline $04 / 26 / 2011$ & 365,430 \\
\hline $04 / 27 / 2011$ & 339,150 \\
\hline $04 / 28 / 2011$ & 349,030 \\
\hline $04 / 29 / 2011$ & 347,830 \\
\hline $04 / 30 / 2011$ & 372,510 \\
\hline $05 / 01 / 2011$ & 340,500 \\
\hline $05 / 02 / 2011$ & 409,000 \\
\hline
\end{tabular}

\begin{tabular}{|c|c|}
\hline Date & $\begin{array}{c}\text { Daily Discharge } \\
\text { Volume (gallons) }\end{array}$ \\
\hline $05 / 03 / 2011$ & 284,300 \\
\hline $05 / 04 / 2011$ & 353,800 \\
\hline $05 / 05 / 2011$ & 356,700 \\
\hline $05 / 06 / 2011$ & 348,000 \\
\hline $05 / 07 / 2011$ & 355,080 \\
\hline $05 / 08 / 2011$ & 358,220 \\
\hline $05 / 09 / 2011$ & 411,800 \\
\hline $05 / 10 / 2011$ & 283,030 \\
\hline $05 / 11 / 2011$ & 358,300 \\
\hline $05 / 12 / 2011$ & 367,450 \\
\hline $05 / 13 / 2011$ & 370,100 \\
\hline $05 / 14 / 2011$ & 323,690 \\
\hline $05 / 15 / 2011$ & 450,000 \\
\hline $05 / 16 / 2011$ & 268,520 \\
\hline $05 / 17 / 2011$ & 333,050 \\
\hline $05 / 18 / 2011$ & 355,320 \\
\hline $05 / 19 / 2011$ & 413,200 \\
\hline $05 / 20 / 2011$ & 240,410 \\
\hline $05 / 21 / 2011$ & 824,610 \\
\hline $05 / 22 / 2011$ & 872,010 \\
\hline $05 / 23 / 2011$ & 850,000 \\
\hline $05 / 24 / 2011$ & 617,830 \\
\hline $05 / 25 / 2011$ & 593,210 \\
\hline $05 / 26 / 2011$ & 748,310 \\
\hline $05 / 27 / 2011$ & 632,160 \\
\hline $05 / 28 / 2011$ & 796,650 \\
\hline $05 / 29 / 2011$ & 732,730 \\
\hline $05 / 30 / 2011$ & 740,000 \\
\hline $05 / 31 / 2011$ & 583,070 \\
\hline $06 / 01 / 2011$ & 784,660 \\
\hline $06 / 02 / 2011$ & 741,800 \\
\hline $06 / 03 / 2011$ & 747,790 \\
\hline $06 / 04 / 2011$ & 573,700 \\
\hline $06 / 05 / 2011$ & 840,000 \\
\hline $06 / 06 / 2011$ & 360,910 \\
\hline $06 / 07 / 2011$ & 129,910 \\
\hline $06 / 08 / 2011$ & 160,890 \\
\hline $06 / 09 / 2011$ & 224,030 \\
\hline $06 / 10 / 2011$ & 230,140 \\
\hline
\end{tabular}




\begin{tabular}{|c|c|}
\hline Date & $\begin{array}{c}\text { Daily Discharge } \\
\text { Volume (gallons) }\end{array}$ \\
\hline $06 / 11 / 2011$ & 235,790 \\
\hline $06 / 12 / 2011$ & 290,000 \\
\hline $06 / 13 / 2011$ & 200,960 \\
\hline $06 / 14 / 2011$ & 239,190 \\
\hline $06 / 15 / 2011$ & 252,530 \\
\hline $06 / 16 / 2011$ & 265,250 \\
\hline $06 / 17 / 2011$ & 257,600 \\
\hline $06 / 18 / 2011$ & 218,800 \\
\hline $06 / 19 / 2011$ & 211,070 \\
\hline $06 / 20 / 2011$ & 270,000 \\
\hline $06 / 21 / 2011$ & 196,430 \\
\hline $06 / 22 / 2011$ & 244,100 \\
\hline $06 / 23 / 2011$ & 244,110 \\
\hline $06 / 24 / 2011$ & 283,000 \\
\hline $06 / 25 / 2011$ & 258,840 \\
\hline $06 / 26 / 2011$ & 250,000 \\
\hline $06 / 27 / 2011$ & 180,500 \\
\hline $06 / 28 / 2011$ & 243,230 \\
\hline $06 / 29 / 2011$ & 269,520 \\
\hline $06 / 30 / 2011$ & 216,890 \\
\hline $07 / 01 / 2011$ & 236,000 \\
\hline $07 / 02 / 2011$ & 241,810 \\
\hline $07 / 03 / 2011$ & 246,430 \\
\hline $07 / 04 / 2011$ & 254,240 \\
\hline $07 / 05 / 2011$ & 227,600 \\
\hline $07 / 06 / 2011$ & 237,150 \\
\hline $07 / 07 / 2011$ & 237,340 \\
\hline $07 / 08 / 2011$ & 243,000 \\
\hline $07 / 09 / 2011$ & 240,970 \\
\hline $07 / 10 / 2011$ & 250,930 \\
\hline $07 / 11 / 2011$ & 251,110 \\
\hline $07 / 12 / 2011$ & 271,460 \\
\hline $07 / 13 / 2011$ & 270,000 \\
\hline $07 / 14 / 2011$ & 216,760 \\
\hline $07 / 15 / 2011$ & 227,260 \\
\hline $07 / 16 / 2011$ & 339,060 \\
\hline $07 / 17 / 2011$ & 210,000 \\
\hline $07 / 18 / 2011$ & 259,080 \\
\hline $07 / 19 / 2011$ & 132,500 \\
\hline
\end{tabular}

\begin{tabular}{|c|c|}
\hline Date & $\begin{array}{c}\text { Daily Discharge } \\
\text { Volume (gallons) }\end{array}$ \\
\hline $07 / 20 / 2011$ & $141,580^{\text {a }}$ \\
\hline $07 / 21 / 2011$ & 246,290 \\
\hline $07 / 22 / 2011$ & 206,800 \\
\hline $07 / 23 / 2011$ & 234,400 \\
\hline $07 / 24 / 2011$ & 233,910 \\
\hline $07 / 25 / 2011$ & 231,490 \\
\hline $07 / 26 / 2011$ & 244,220 \\
\hline $07 / 27 / 2011$ & 273,810 \\
\hline $07 / 28 / 2011$ & 253,860 \\
\hline $07 / 29 / 2011$ & 219,010 \\
\hline $07 / 30 / 2011$ & 676,700 \\
\hline $07 / 31 / 2011$ & 840,000 \\
\hline $08 / 01 / 2011$ & 429,890 \\
\hline $08 / 02 / 2011$ & 560,140 \\
\hline $08 / 03 / 2011$ & 536,500 \\
\hline $08 / 04 / 2011$ & 562,010 \\
\hline $08 / 05 / 2011$ & 571,300 \\
\hline $08 / 06 / 2011$ & 559,400 \\
\hline $08 / 07 / 2011$ & 482,870 \\
\hline $08 / 08 / 2011$ & 519,010 \\
\hline $08 / 09 / 2011$ & 609,370 \\
\hline $08 / 10 / 2011$ & 419,220 \\
\hline $08 / 11 / 2011$ & 638,840 \\
\hline $08 / 12 / 2011$ & 381,680 \\
\hline $08 / 13 / 2011$ & 547,100 \\
\hline $08 / 14 / 2011$ & 479,910 \\
\hline $08 / 15 / 2011$ & 550,130 \\
\hline $08 / 16 / 2011$ & 634,000 \\
\hline $08 / 17 / 2011$ & 436,040 \\
\hline $08 / 18 / 2011$ & 464,900 \\
\hline $08 / 19 / 2011$ & 443,750 \\
\hline $08 / 20 / 2011$ & 195,400 \\
\hline $08 / 21 / 2011$ & 223,370 \\
\hline $08 / 22 / 2011$ & 254,880 \\
\hline $08 / 23 / 2011$ & 255,130 \\
\hline $08 / 24 / 2011$ & 269,680 \\
\hline $08 / 25 / 2011$ & 301,240 \\
\hline $08 / 26 / 2011$ & 287,460 \\
\hline $08 / 27 / 2011$ & 267,270 \\
\hline
\end{tabular}




\begin{tabular}{|c|c|}
\hline Date & $\begin{array}{c}\text { Daily Discharge } \\
\text { Volume (gallons) }\end{array}$ \\
\hline $08 / 28 / 2011$ & 282,470 \\
\hline $08 / 29 / 2011$ & 297,500 \\
\hline $08 / 30 / 2011$ & 340,000 \\
\hline $08 / 31 / 2011$ & 305,870 \\
\hline $09 / 01 / 2011$ & 727,880 \\
\hline $09 / 02 / 2011$ & 667,050 \\
\hline $09 / 03 / 2011$ & 612,160 \\
\hline $09 / 04 / 2011$ & 771,170 \\
\hline $09 / 05 / 2011$ & 643,130 \\
\hline $09 / 06 / 2011$ & 637,600 \\
\hline $09 / 07 / 2011$ & 708,680 \\
\hline $09 / 08 / 2011$ & 846,670 \\
\hline $09 / 09 / 2011$ & 515,430 \\
\hline $09 / 10 / 2011$ & 737,580 \\
\hline $09 / 11 / 2011$ & 581,810 \\
\hline $09 / 12 / 2011$ & 823,710 \\
\hline $09 / 13 / 2011$ & 587,830 \\
\hline $09 / 14 / 2011$ & 573,770 \\
\hline $09 / 15 / 2011$ & 710,430 \\
\hline $09 / 16 / 2011$ & 605,010 \\
\hline $09 / 17 / 2011$ & 841,310 \\
\hline $09 / 18 / 2011$ & 670,000 \\
\hline $09 / 19 / 2011$ & 501,390 \\
\hline $09 / 20 / 2011$ & 659,100 \\
\hline $09 / 21 / 2011$ & 678,170 \\
\hline $09 / 22 / 2011$ & 631,570 \\
\hline $09 / 23 / 2011$ & 561,440 \\
\hline $09 / 24 / 2011$ & 575,410 \\
\hline $09 / 25 / 2011$ & 555,510 \\
\hline $09 / 26 / 2011$ & 619,200 \\
\hline $09 / 27 / 2011$ & 550,620 \\
\hline $09 / 28 / 2011$ & 532,270 \\
\hline $09 / 29 / 2011$ & 359,510 \\
\hline
\end{tabular}

\begin{tabular}{|c|c|}
\hline Date & $\begin{array}{c}\text { Daily Discharge } \\
\text { Volume (gallons) }\end{array}$ \\
\hline $09 / 30 / 2011$ & 422,360 \\
\hline $10 / 01 / 2011$ & 317,850 \\
\hline $10 / 02 / 2011$ & 294,840 \\
\hline $10 / 03 / 2011$ & 293,240 \\
\hline $10 / 04 / 2011$ & 263,230 \\
\hline $10 / 05 / 2011$ & 403,200 \\
\hline $10 / 06 / 2011$ & 381,960 \\
\hline $10 / 07 / 2011$ & 354,380 \\
\hline $10 / 08 / 2011$ & 329,400 \\
\hline $10 / 09 / 2011$ & 382,710 \\
\hline $10 / 10 / 2011$ & 324,020 \\
\hline $10 / 11 / 2011$ & 397,900 \\
\hline $10 / 12 / 2011$ & 307,500 \\
\hline $10 / 13 / 2011$ & 461,850 \\
\hline $10 / 14 / 2011$ & 290,990 \\
\hline $10 / 15 / 2011$ & 129,750 \\
\hline $10 / 16 / 2011$ & 90,520 \\
\hline $10 / 17 / 2011$ & 134,240 \\
\hline $10 / 18 / 2011$ & 118,940 \\
\hline $10 / 19 / 2011$ & 166,510 \\
\hline $10 / 20 / 2011$ & 199,410 \\
\hline $10 / 21 / 2011$ & 194,160 \\
\hline $10 / 22 / 2011$ & 178,620 \\
\hline $10 / 23 / 2011$ & 161,510 \\
\hline $10 / 24 / 2011$ & 186,020 \\
\hline $10 / 25 / 2011$ & 179,800 \\
\hline $10 / 26 / 2011$ & 216,620 \\
\hline $10 / 27 / 2011$ & 244,280 \\
\hline $10 / 28 / 2011$ & 237,000 \\
\hline $10 / 29 / 2011$ & 246,000 \\
\hline $10 / 30 / 2011$ & 237,670 \\
\hline $10 / 31 / 2011$ & 284,020 \\
\hline & \\
\hline & \\
\hline
\end{tabular}

a. Estimated flow volume, see Section 5.2. 
ATR COMPLEX WASTE SYSTEMS DATA SHEET (1)

INTEGPATOR READINGS

\begin{tabular}{|c|c|c|c|c|}
\hline & & & & \\
\hline \multirow{2}{*}{\begin{tabular}{|c|} 
Take integrator \\
Rastings \\
Oro0.1900 \\
Daty
\end{tabular}} & \multirow[t]{2}{*}{ Cols Waste Total Fow (Gotons) } & \multicolumn{3}{|c|}{$\begin{array}{c}\text { Cold Weste Pumps Pan Time } \\
\text { Dascurs) }\end{array}$} \\
\hline & & No. 1 & No. 2 & No. 3 \\
\hline Toders Resoding & 54127896 & $324 / 6: 6$ & $3499 \% 7$ & 4610.8 \\
\hline Prentous Day & 54116968 & 32416.6 & $34987 \cdot 7$ & $6607 \cdot 5$ \\
\hline Toto & 10924 & 2 & 13.9 & 3.3 \\
\hline
\end{tabular}

NON-CWP DATA REDACTED
* Paver securcel to flow tolabijer for 6 haves 20 minates for

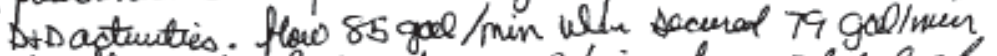
wher flow rostaded. Useal $85 \mathrm{gga} / \mathrm{min}$ for a toral of $32,300 \mathrm{gal}$ of fllow net rawdad, flow total $43,228-81111,141,580$

QIIII) $731 / 11$

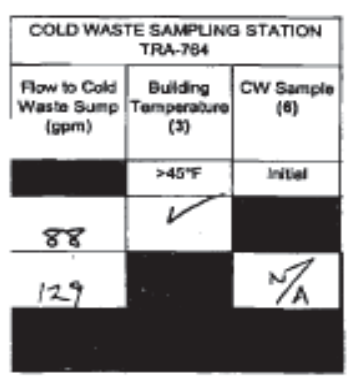

NON-CWP DATA REDACTED

PFLSRAO REVEW (NOTE 2) MIOS: SSAT DAYSHIFT: IO ROTATING DAYS: 